The research program of the Center for Economic Studies (CES) produces a wide range of theoretical and empirical economic analyses that serve to improve the statistical programs of the U.S. Bureau of the Census. Many of these analyses take the form of CES research papers. The papers are intended to make the results of CES research available to economists and other interested parties in order to encourage discussion and obtain suggestions for revision before publication. The papers are unofficial and have not undergone the review accorded official Census Bureau publications. The opinions and conclusions expressed in the papers are those of the authors and do not necessarily represent those of the U.S. Bureau of the Census. Republication in whole or part must be cleared with the authors.

\title{
LEASING, ABILITY TO REPOSSESS, AND DEBT CAPACITY
}

\author{
by
}

Andrea L. Eisfeldt *

Northwestern University

and

Adriano A. Rampini *
Duke University

\section{CES 07-19 June, 2007}

All papers are screened to ensure that they do not disclose confidential information. Persons who wish to obtain a copy of the paper, submit comments about the paper, or obtain general information about the series should contact Sang V. Nguyen, Editor, Discussion Papers, Center for Economic Studies, Bureau of the Census, 4600 Silver Hill Road, 2K132F, Washington, DC 20233, (301-763-1882) or INTERNET address sang.v.nquyen@censu.s.gov. 


\begin{abstract}
This paper studies the financing role of leasing and secured lending. We argue that the benefit of leasing is that repossession of a leased asset is easier than foreclosure on the collateral of a secured loan, which implies that leasing has higher debt capacity than secured lending. However, leasing involves agency costs due to the separation of ownership and control. More financially constrained firms value the additional debt capacity more and hence lease more of their capital than less constrained firms. We provide empirical evidence consistent with this prediction. Our theory is consistent with the explanation of leasing by practitioners, namely that leasing "preserves capital," which the academic literature considers a fallacy.
\end{abstract}

JEL Classification: D23, D92, E22, G31, G32, G33.

Keywords: Leasing, secured debt, collateral, repossession, debt capacity, capital structure.

* We thank S. Arping, D. Baird, F. Buera, A. Collard-Wexler, M. Fishman, K. Hagerty, R. Jagannathan, D. Jenter, S. Kaplan, M. Petersen, C. Rampini, A. Raviv, D. Scharfstein, M. Spiegel (the editor), A. Sufi, S. Viswanathan, an anonymous referee, and seminar participants at Northwestern, Stanford, Berkeley, Duke, LSE, UNC, Wharton, Illinois, Imperial College, Ohio State, Yale, HBS, Chicago, Colorado, Minnesota, the Federal Reserve Bank of Philadelphia, San Francisco, Chicago, and New York, the 2006 SED Annual Meeting, the 2006 NBER Summer Institute in "Capital Markets and the Economy" and "Corporate Finance," the 2006 EFA Annual Meeting, and the 2007 AFA Annual Meeting for comments, Lynn Riggs for assistance with the data, and Olesya Baker for excellent research assistance. Research results and conclusions expressed are those of the authors and do not necessarily reflect the views of the Census Bureau. This paper has been screened to ensure that no confidential data are revealed. 


\section{Introduction}

The ability of the lessor to repossess an asset is a major benefit of leasing. This ability to repossess allows a lessor to implicitly extend more credit than a lender whose claim is secured by the same asset. The debt capacity of leasing thus exceeds the debt capacity of secured lending. This makes leasing valuable to financially constrained firms.

When an asset is leased, however, the asset is under the control of a user who is not the owner. Leasing hence involves a separation of ownership and control, which is costly due to agency problems. The benefit of leasing in terms of its higher debt capacity has to be weighed against the cost due to the agency problem. The benefit will outweigh the cost for firms which are more financially constrained, while firms which are less constrained or unconstrained prefer to own assets.

In the U.S. bankruptcy code, leasing and secured lending are treated quite differently. In Chapter 11, the lessee must either assume the lease, which means keeping control of the asset and continuing to make the specified payments, or reject the lease and return the asset. In contrast, the collateral which secures the claim of a secured lender is subject to automatic stay in Chapter 11, which prohibits recovery of or foreclosure on the property. Thus, in bankruptcy it is much easier for a lessor to regain control of an asset than it is for a secured lender to repossess it. The ease with which a lessor and a lender can repossess an asset in bankruptcy moreover affects their bargaining power outside of bankruptcy and hence affects what they can reasonably expect to be repaid outside of bankruptcy.

Thus, U.S. statutes clearly make repossession easier for a lessor than for a secured lender. More generally, and in most legal environments, one might expect that it is typically easier for the owner of an asset to regain control of it than it is for a lender who takes a security interest in an asset to repossess it. Allocating ownership to the agent providing financing strengthens the financier's claim by facilitating repossession. This in turn allows the financier to extend more credit. Allocating ownership to the user of the capital, in contrast, is efficient since it minimizes the agency costs due to the separation of ownership and control. It is this basic tradeoff which we think determines to a large extent whether it is advantageous to lease, which means that the financier retains ownership, or buy, which means that the financier merely takes a security interest in the asset.

Interestingly, the main argument for leasing typically given by leasing firms is that it "conserves cash," provides "100 percent financing," or "preserves credit lines." This is indeed the advantage of leasing as argued above, since the debt capacity of leasing exceeds the debt capacity of secured lending. In contrast, this argument is generally considered a fallacy in the academic literature. ${ }^{1}$ Practitioners in turn argue that the

\footnotetext{
${ }^{1}$ For example, Brealey, Myers, and Allen (2005), list "leasing preserves capital" as one of the dubious
} 
academic literature has gotten the answer wrong. ${ }^{2}$ We are the first, to the best of our knowledge, to provide a model which explicitly captures the primary motivation for leasing according to practitioners and thus shows that the idea that "leasing preserves capital" is not a misconception.

There is an extensive literature on leasing in finance, but its focus is almost exclusively on the tax-incentives for leasing in an otherwise frictionless Modigliani-Miller type environment, following, e.g., Miller and Upton (1976). ${ }^{3}$ In contrast, agency problems have received far less attention. That leasing involves agency costs due to the separation of ownership and control has been recognized for example by Alchian and Demsetz (1972). However, the fact that leasing is associated with a repossession advantage relative to secured lending has not been modeled. Nor has the literature argued that the greater ability to repossess means that the debt capacity of leasing is higher, which is a link that is crucial to understanding the relationship between leasing and financial constraints. The repossession advantage has been discussed informally in the literature. Most notably, Smith and Wakeman (1985) provide a discussion of both tax and nontax determinants of the lease vs. buy decision and argue that (p. 899) "it is simpler for a lessor to regain physical possession of a leased asset either prior to or after the declaration of bankruptcy than for a secured debtholder to acquire the pledged asset." Their concluding list of eight nontax reasons to lease however does not include the "leasing preserves capital" explanation due to the greater ability of the lessor to repossess the asset.

Beyond providing an explicit analysis of the effect of financial constraints on the leasing decision, our model makes several theoretical contributions. First, a common critique of theories based on bankruptcy costs is that the probability of bankruptcy is typically quite small and does not vary much across firms. Our model shows that variation in available internal funds affects the leasing decision even controlling for the probability of bankruptcy (which is held constant in the model). Empirically, variation in the amount of internal funds across firms is likely to be larger than variation in bankruptcy probabilities and thus this variation has the potential to generate a quantitatively important effect on

reasons for leasing, arguing that a firm could simply borrow the amount of the purchase price instead of leasing. Ross, Westerfield, and Jaffe (2002) include "one hundred-percent financing" on a similar list. Schallheim (1994) notes that (p. 7) “... 100 percent financing remains a popular advertising approach, especially to small lessee firms or for venture leases."

${ }^{2}$ For example, Andrew and Gilstad (2005) write that "business schools typically teach that leasing is a zero-sum game. However, the economic assumptions that lead to this belief often are not true. These incorrect assumptions have caused serious confusion and bias in lease evaluation for more than a generation." They argue that there is a "failure to seriously consider the differences that exist between the financial characteristics of the lessor and the lessee beyond tax rates."

${ }^{3} \mathrm{~A}$ more extensive review of the literature is provided in Section 5 below. 
the leasing decision. As a result, we stress the effect of leasing on debt capacity rather than the effect on bankruptcy costs which has been previously emphasized. Second, our model also addresses the critique that models with collateral constraints depend crucially on excluding a rental market for capital. We show that when the enforcement problem of lessors, and not just lenders, is taken into account explicitly, the introduction of a leasing market for capital relaxes financial constraints, but does not eliminate them. Contract enforcement implies that the leasing fee needs to be paid up front and thus optimal leasing contracts offer close to but not quite "100 percent financing." Third, we also show that in equilibrium the leasing rate, and the lessor's cost of capital, are such that most firms are not indifferent between leasing and buying, but prefer one or the other. A competitive leasing market implies that the rate that lessors charge does not increase to reflect the full value of the contract to all lessees. Finally, the availability and distribution of internal funds overall affects the equilibrium price to rental ratio. Our theory suggests that the incidence of credit constraints may play a role in explaining the observed time series variation in this ratio.

Our model implies that the decision to lease vs. buy depends on firms' internal funds. We explicitly derive the empirical predictions of our theory for the relationship between leasing and financial variables commonly used in empirical studies. We show that firms which appear more financially constrained lease a considerably larger fraction of their capital using micro data from the U.S. Census of Manufactures and Compustat. Specifically, smaller firms, firms which pay lower dividends (relative to assets), have lower cash flow (relative to assets), and have higher Tobin's $q$ lease a significantly larger fraction of their capital. Additional evidence consistent with our prediction that more financially constrained firms lease more is provided by Sharpe and Nguyen (1995). ${ }^{4}$ Our data allows measurement of the fraction of capital leased for structures and equipment separately. We find that leasing is considerably higher for structures than for equipment, which is consistent with our model since equipment is likely subject to higher moral hazard costs and typically depreciates faster, reducing the impact of the ability to repossess. Moreover, we find a similar relationship between measures of financial constraints and leasing for structures as well as equipment, albeit the latter is somewhat weaker.

Quantitatively, leasing is of first order importance as a source of financing. Leasing is of comparable importance to long-term debt even for relatively large firms: the fraction of capital that firms lease in merged Census-Compustat data is $16 \%$ which is similar

\footnotetext{
${ }^{4}$ Sharpe and Nguyen (1995) find a significant relationship between financial variables and operating leases, but not capital leases. This supports our theory since operating leases typically enjoy the repossession advantage which we argue is crucial, while capital leases typically do not.
} 
to the long-term debt to assets ratio of 19\%. Graham, Lemmon, and Schallheim (1998) report that operating leases, capital leases, and debt are $42 \%, 6 \%$, and $52 \%$ of fixed claims, respectively, in 1981-1992 Compustat data. Thus, leasing seems critical for understanding the capital structure of firms. Moreover, we show that for small firms leasing is even more important; firms in the smallest decile lease $46 \%$ of their capital. Leasing may hence be the largest source of external finance for these firms.

Interestingly, and maybe somewhat surprisingly given its quantitative importance, leasing has been essentially ignored in the theoretical and empirical literature on investment in both finance and macroeconomics. The finance literature studies the effect of financial constraints on investment (see, e.g., Fazzari, Hubbard, and Petersen (1988)), but does not consider firms' ability to deploy more capital by leasing it in the theory, or adjust investment for changes in the amount of capital leased in the empirical work. The macroeconomics literature considers the role of irreversibility and adjustment costs on firm investment (see, e.g., Abel and Eberly (1994)), but does not take into account leased capital. The maintained assumption in the theory may be that the same adjustment costs apply when capital is leased, but this is not reflected in the empirical work. We discuss several additional implications of the effect of financial constraints on leasing for corporate finance and macroeconomics in the conclusions.

\section{Leases and the Law, Taxation, and Accounting}

The main difference between leasing and secured lending from our vantage point is its treatment in bankruptcy. We start by discussing the main difference between the treatment of a true lease and a claim with a security interest in bankruptcy, that is, the difference from a legal perspective. We then provide a more detailed discussion of the differences from the taxation and accounting perspective as well. An overview of the classifications for legal, tax and accounting purposes is provided in Table 1. Broadly speaking, the picture is as follows: While there are differences between the three classifications, they are actually highly correlated. Moreover, the differences across different types of leases and secured debt are a matter of degree since the classification of a specific transaction depends on a variety of characteristics. In particular, the ability to repossess gradually decreases as a lease starts to look more like secured debt, and hence as more of the property rights are allocated to the user. ${ }^{5}$ There seems to be an important link

\footnotetext{
${ }^{5}$ Ayotte and Gaon (2005) provide an interesting related argument regarding the role of asset backed securities, leases, and secured debt given differences in "bankruptcy remoteness." In their analysis, tougher claims limit inefficient continuation. For an analysis of secured debt, see Stulz and Johnson
} 
between the retension of property rights and the ability to repossess.

Bankruptcy law and commercial law distinguish between a "true lease" and a lease intended as security, which means that the lease merely establishes a "security interest" in the asset. ${ }^{6}$ A true lease is an executory contract. This means that the obligations of both parties to the contract remain largely to be performed. In a true lease, the lessor retains effective ownership. In Chapter 11, the lessee must either assume the lease or reject the lease. If the lessee assumes the lease, he has to continue to make the scheduled payments and, if there has been a default, it has to be cured to assume the lease. In addition, the lease becomes a post-petition liability and the lessor has hence effectively a first priority claim. If the lessee rejects the lease, he has to return the asset to the lessor. Any additional claims that the lessor has are then unsecured claims in bankruptcy.

If the lease is intended as security, or recharacterized by the bankruptcy judge as such, the lessor is effectively treated like any other secured lender. That is, the lessee acquires effective ownership. Most importantly the collateral is then subject to automatic stay, which prohibits recovery of or foreclosure on the collateral. The debtor is typically allowed to continue to use the asset. A secured lender may be entitled to protection against a decline in collateral value over the course of a bankruptcy case, but the inconvenience of automatic stay is not sufficient to obtain adequate protection. In short, while the secured lender is not completely unprotected, he is clearly in a much weaker position than the lessor in a true lease. ${ }^{7}$

Whether or not the lease is a true lease, or merely establishes a security interest, depends on the duration of the lease (relative to the economic life of the asset), the extent to which the lessee is bound to renew the lease for the remaining life or bound to become the owner, the extent to which the lessee has options to renew or become the owner for no additional (or nominal) payments, among other factors (see Table 1 for details). The more the lease seems to allocate control to the lessee and the more the lessee seems to be expected to end up as the residual claimant of the asset, the more likely the lessee is to be treated as effective owner. ${ }^{8}$ Thus, "economic realities" rather than form are (1985), who argue that secured debt limits the underinvestment problem.

${ }^{6}$ See Ayer and Bernstein (2002) and Ayer, Bernstein, and Friedland (2003, 2004a,b), who address Chapter 11 professionals, for a clear discussion of the issues analyzed in this section.

${ }^{7}$ See Mayer (2005) for a detailed list of the consequences of recharacterization of a lease as intended as a security interest only.

${ }^{8}$ Thus, the hold-up problem induced by leasing cannot be easily solved by giving the lessee an option to buy (see, e.g., Nöldeke and Schmidt (1998)), since such purchase options can lead the bankruptcy court to recharacterize the lease as intended as security interest only, thereby eliminating the repossession advantage. We might hence expect purchase options to be used less frequently when the lessee values the tougher lease claims as a way to relax financial constraints. 
critical for the determination (see, e.g., Mayer (2005)). In practice, lessors are concerned about preventing recharacterization, as evidenced by the fact that strategies to avoid recharacterization and the enforcement of leases as true leases are recurrent themes in the applied leasing literature. ${ }^{9}$ From an empirical perspective, this means that leases may not always be enforced as true leases in bankruptcy. But what is critical for our argument and empirical work is that the probability that they enjoy the high priority of a true lease is higher than that of a secured loan. ${ }^{10}$

The classification criteria from the perspective of taxation and accounting have a similar spirit (see again Table 1 for details). The tax law distinguishes between a "true lease" and a "conditional sales contract." To qualify as a true lease, a lower bound on the extent to which the lessor is the residual claimant has to be met. In addition, an upper bound on the extent of control of the asset by the lessee cannot be exceeded. The accounting rules in turn distinguish between an "operating lease" and a "capital lease." The criteria for classification are however quite similar to the criteria for tax purposes.

The tax and accounting classification of course affect who treats the asset as a capital asset and depreciates it for tax and accounting purposes, respectively. There is however a connection between the various classifications. Operating leases are usually true leases for tax and legal purposes. Capital leases are often considered conditional sales contracts for tax purposes with two important caveats: First, a lease with a term exceeding $75 \%$ of the asset's economic life but not exceeding $80 \%$ will be a capital lease for accounting purposes but a true lease for tax purposes. Second, by making different assumptions about economic life, residual value, and so on for accounting and tax purposes, a lessee has some additional leeway to have a capital lease treated as a true lease for tax purposes. Importantly, whether a lease is considered a true lease for tax purposes and an operating lease for accounting purposes may affect how it will be characterized for legal purposes and hence may affect its treatment in bankruptcy.

To sum up, the ability to repossess is an advantage of true leases from the legal perspective. From the accounting perspective, this advantage is hence primarily enjoyed by operating leases, although some capital leases may enjoy the same advantage. This

\footnotetext{
${ }^{9}$ See, e.g., Mayer (2005) for suggestions on how to structure contracts to avoid recharacterization and Califano (2002) for evidence on enforcement.

${ }^{10} \mathrm{In}$ addition to the repossession advantage, there is a special type of lease contract called a "finance lease" defined by the Uniform Commercial Code (U.C.C. $\S 2 \mathrm{~A}$ ), which gives a lessor, who is not the manufacturer of the leased goods, a claim to the lessee's payments regardless of any defects in the leased goods (at times referred to as a "hell or high water" clause). The lessee can bring claims related to defects only against the supplier of the goods. The provisions for "finance leases" in the sense of U.C.C. $\S 2 \mathrm{~A}$ may be an additional reason to lease.
} 
is important in interpreting empirical work which uses accounting data or Census data which is based on accounting classifications as we discuss below.

\section{Leasing versus Secured Lending}

\subsection{Model}

The economy has two dates, 0 and 1. There is a continuum of agents of measure one. Agents have identical preferences and access to the same projects, but differ in the amount of internal funds that they have, i.e., in their idiosyncratic endowment. This idiosyncratic amount of internal funds determines an agent's decision to lease or buy, and borrow or lend. The preferences of agents are

$$
d_{0}+\sum_{s \in \mathcal{S}} \pi(s) d_{1}(s)
$$

where $d_{0}$ and $d_{1}(s)$ are the (non-negative) dividends at time 0 and in state $s$ at time 1 , where the state $s$ is idiosyncratic and there are two states, high $(H)$ and low $(L)$, i.e., $\mathcal{S}=\{H, L\} .{ }^{11}$ At time 0 , each agent observes his idiosyncratic internal funds $e \in \mathcal{E} \subset \mathbb{R}_{+}$, which are distributed independently and identically across agents with density $p(e)$ on $\mathcal{E}$. Agents face the same probabilities of the two states at time 1 , and these states are independent across agents.

Each agent has access to a concave production technology which produces a cash flow at time 1 of $a(s) k^{\alpha}$, where $k$ is the amount of capital deployed by the agent, $a(s)$ is the stochastic productivity which depends on the state $s$, and $\alpha \in(0,1)$. We assume that $a(H)=1$ and $a(L)=0$, so cash flow is only generated in state $H^{12}$ Agents can buy capital $\left(i_{b}\right)$ and/or lease capital $\left(i_{l}\right)$, and both $i_{b}$ and $i_{l}$ are non-negative. Bought (or owned) capital and leased capital are assumed to be perfect substitutes in production, i.e., $k=i_{b}+i_{l}$.

Capital can be bought at a price of 1 at time 0 , depreciates at a rate of $\delta \in(0,1)$, and the (depreciated) owned capital can be sold at a price of 1 per unit of capital at time $1 .^{13}$ Purchases of capital can be partially financed by borrowing in a state contingent way. A promise to repay $R b(s)$ in state $s$ at time 1 gives the agent funds of $\pi(s) b(s)$ at time 0 ,

\footnotetext{
${ }^{11}$ For simplicity, we assume risk neutrality and no discounting, but neither assumption is critical. In fact, a previous version of this paper featured a model with risk averse agents and discounting.

${ }^{12}$ This assumption simplifies the analysis, but is not critical. No cash flow uncertainty is a special case of this formulation where $\pi(H)=1$. Our main results carry over to this case.

${ }^{13} \mathrm{We}$ assume here that the price on new and used capital is the same, in contrast to Eisfeldt and Rampini (2007), in order to focus on the lease vs. buy decision.
} 
where $R$ is the gross interest rate which will be determined in equilibrium. ${ }^{14}$ Loans are provided by competitive, perfectly diversified financial intermediaries, as in Diamond (1984), which are financed by the agents' savings. The financial intermediaries make zero profits and hence we do not need to consider them explicitly. We can however think of them as being owned by the unconstrained agents. We model leasing firms similarly (see below).

Borrowing is constrained in the following ways: First, promises have to be collateralized and there is a deadweight cost to repossession of fraction $1-\theta$ of the depreciated capital when capital is repossessed. Thus, the lender can repossess only a fraction $\theta$ of the resale value of capital, i.e., the collateral constraint is, $\forall s \in \mathcal{S}$,

$$
R b(s) \leq \theta i_{b}(1-\delta)
$$

We assume, similar to Hart and Moore (1994) and Kiyotaki and Moore (1997), that the agent has all the bargaining power ex post, except that the lender can threaten to repossess the capital underlying the loan. The borrower will make a take it or leave it offer equal to the value of the repossessed capital and the lender will accept this offer. Thus, the agent cannot promise to pay more than the resale value of repossessed capital and we have the stated collateral constraint.

Second, repayments have to be made either with cash flows or with repossessed capital, i.e., there is the following repayment constraint, $\forall s \in \mathcal{S}$ :

$$
R b(s) \leq a(s) k^{\alpha}+\theta i_{b}^{r}(s)(1-\delta)
$$

where $i_{b}^{r}(s)$ is the (non-negative) amount of capital repossessed in equilibrium in state $s .{ }^{15}$ Since $a(L)=0$, promises to borrow against the low state will have to be repaid by having capital repossessed. Moreover, we assume that $a(H) k^{\alpha}>\theta k(1-\delta)$ in the relevant range, which implies that the repayment in the high state can be made entirely out of cash flow.

Third, the lender cannot repossess more capital than the agent owns, i.e., there is a repossession constraint that, $\forall s \in \mathcal{S}$,

$$
i_{b}^{r}(s) \leq i_{b}
$$

\footnotetext{
${ }^{14}$ Similar results can be obtained if borrowing is exogenously restricted to be non-state contingent. In practice, borrowing may be rendered effectively state-contingent by ex post contract renegotiation as in Benmelech and Bergman (2006).

${ }^{15}$ For related models of collateralized lending in which agents who default incur deadweight costs in equilibrium see, e.g., Diamond (1984), Lacker (2001), and Rampini (2005).
} 
Finally, we assume that cash flows are private information, and so it has to be incentive compatible for agents to announce the state $s$ truthfully. In particular the agent with the high cash flow has to prefer to announce that the cash flow is high and make the appropriate repayment $R b(H)$ and incur the deadweight cost of repossession $i_{b}^{r}(H)(1-\delta)(1-\theta)$, rather than to pretend to have low cash flow and make the corresponding repayment and incur the corresponding deadweight cost, i.e., we have the incentive compatibility constraint

$$
R b(H)+i_{b}^{r}(H)(1-\delta)(1-\theta) \leq R b(L)+i_{b}^{r}(L)(1-\delta)(1-\theta)
$$

Since $a(L)=0$, agents who are borrowing and have a low cash flow realization cannot pretend to have high cash flow since they cannot make cash payments.

Agents who have high internal funds save part of their internal funds and lend them to constrained agents. To give them incentives to announce the state truthfully, we need to also impose that

$$
R b(L) \leq R b(H)
$$

The last two constraints together simply imply that when an agent is saving, he saves in an non-contingent way $(b(H)=b(L))$, whereas when an agent is borrowing, this last constraint is redundant.

Capital can also be leased. The benefit of leasing is that the leasing company can costlessly repossess the (depreciated) leased capital at time 1 and thus its repossession technology is better than the repossession technology of the lenders (who can only repossess a fraction $\theta$ of capital). ${ }^{16}$ The cost of leasing is that leased capital is subject to an agency problem with regard to the care with which it is used or maintained and hence it depreciates at a rate $\delta_{l} \in(0,1)$, where $\delta_{l}>\delta$. The idea that separating ownership and control results in greater depreciation of capital goes back to at least Alchian and Demsetz (1972). ${ }^{17}$ The leasing contract, which is derived below, is as follows: An agent who leases $i_{l}$ units of capital pays a leasing fee of $u_{l} i_{l}$ at time 0 (where $u_{l}$ is the leasing rate per unit of capital which will turn out to be the user cost of leased capital). The depreciated leased capital is simply returned to the lessor at time 1 and no other payments to the lessor are required at that time. This implies a leasing rate per unit of capital of $u_{l}=1-R^{-1}\left(1-\delta_{l}\right){ }^{18}$

\footnotetext{
${ }^{16} \mathrm{We}$ assume that the lessor can repossess the entire (depreciated) leased capital for simplicity, but there is a benefit to leasing as long as the fraction that the lessor can repossess exceeds $\theta$.

${ }^{17}$ The costs of separating ownership and control might also involve monitoring costs or costs due to suboptimal utilization of the asset because of use restrictions, but we abstract from these for simplicity.

${ }^{18}$ We assume that $1-\delta_{l}>\theta(1-\delta)$ to ensure that the agency problem is not so severe that the leased
} 


\subsection{Agent's Problem}

An agent with internal funds $e \in \mathcal{E}$ takes the interest rate $R$ and the leasing fee $u_{l}$ as given, and maximizes his utility (1) by choosing dividends $\left\{d_{0}, d_{1}(s)\right\}$, the amount of capital to lease $i_{l}$, purchases of capital $i_{b}$, the amount of capital that is allowed to be repossessed in order to repay loans in each state $i_{b}^{r}(s)$, and the amount to borrow against each state $b(s)$, subject to budget constraints at time 0 and in state $s$ at time 1 ,

$$
\begin{gathered}
d_{0}+u_{l} i_{l}+i_{b} \leq e+\sum_{s \in \mathcal{S}} \pi(s) b(s) \\
d_{1}(s)+R b(s) \leq a(s) k^{\alpha}+i_{b}(1-\delta)-i_{b}^{r}(s)(1-\delta)(1-\theta), \quad \forall s \in \mathcal{S},
\end{gathered}
$$

where $k \equiv i_{l}+i_{b}$, the collateral constraints (2), the repayment constraints (3), the repossession constraints (4) as well as the incentive compatibility constraints (5) and (6). Before characterizing the solution to the agent's problem, we discuss the problem of a leasing firm and define an equilibrium.

\subsection{Lessor's Problem}

A competitive lessor maximizes profits taking the equilibrium leasing charge $u_{l}$ as given. To provide an amount of capital $i_{l}$ to the lessee, the lessor needs to purchase that amount of capital at time 0 . Since there is no deadweight cost when the lessor repossesses the capital, we can assume that all leased capital is repossessed without loss of generality and the lessor will be able to sell the amount of capital $i_{l}\left(1-\delta_{l}\right)$ at a price of 1 at time 1 . Discounting cash flows at time 1 at rate $R$ the lessor's problem is

$$
\max _{i_{l}} u_{l} i_{l}-i_{l}+R^{-1} i_{l}\left(1-\delta_{l}\right)
$$

The first order condition implies that $u_{l}=1-R^{-1}\left(1-\delta_{l}\right)$ and the lessor makes zero profits in equilibrium. Thus, we can assume that the unconstrained agents own the leasing firms and hence leasing firms do not face financial constraints and discount cash flows at their endogenous cost of capital, $R$.

Notice that the leasing charge $u_{l}$ is paid up front. This is due to the fact that the agent cannot commit to make extra payments at time 1 , since all the lessor can do is recover $i_{l}\left(1-\delta_{l}\right)$. Moreover, leasing can be interpreted as involving an implicit loan $R^{-1} i_{l}\left(1-\delta_{l}\right)$. This implicit loan exceeds the amount that a secured lender would be willing to lend per unit of capital (which is $R^{-1} \theta(1-\delta)$ ) given our assumption. This additional debt

capital depreciates so much that less remains after depreciation than the amount of depreciated owned capital that a secured lender could repossess. 
capacity is the benefit of leasing and it is in this sense that leasing "preserves capital." Leasing provides almost "100 percent financing" since the lessee needs internal funds in the amount of the one period user cost only. Taking the contract enforcement problem of the lessor explicitly into account is critical, since it implies that optimal leasing contracts require some internal funds up front which means that a leasing market for capital relaxes collateral constraints, but does not eliminate them.

\subsection{Equilibrium}

An equilibrium in this economy is an interest rate $R$, a leasing rate $u_{l}=1-R^{-1}\left(1-\delta_{l}\right)$, and an allocation, such that agents maximize, taking the interest rate and leasing rate as given, and the capital market clears. The capital market clears if the total aggregate direct net borrowing plus the total amount of financing required by the leasing firms equals zero, i.e.,

$$
\sum_{e \in \mathcal{E}} p(e) \sum_{s \in \mathcal{S}} \pi(s) b(s ; e)+\sum_{e \in \mathcal{E}} p(e) R^{-1} i_{l}(e)\left(1-\delta_{l}\right)=0
$$

The first term is the aggregate explicit net debt and the second term is the aggregate implicit leasing debt. The price to rental ratio $1 / u_{l}$ is determined in equilibrium and depends on the availability and distribution of internal funds. A reduction in agents' internal funds raises the price to rental ratio in our model.

\subsection{Characterization}

Agents' lease vs. buy decision depends on their internal funds. Broadly speaking, the solution is as follows: ${ }^{19}$ Agents who are sufficiently financially constrained lease capital; agents who are less constrained buy capital and (typically) borrow against it, which means that capital is repossessed in the low state; and agents who are unconstrained lend.

Figure 1 illustrates the choice between leasing and buying as a function of internal funds (on the x-axis) in a numerical example: ${ }^{20}$ Total investment, or firm size, is increasing in the amount of internal funds (top left panel); leasing is decreasing in internal funds (top and middle left panel); total debt is decreasing in internal funds, while explicit debt is high for intermediate values of internal funds (top right panel) and so is repossessed capital (middle right panel).

\footnotetext{
${ }^{19} \mathrm{~A}$ detailed analytical characterization is provided in the appendix.

${ }^{20}$ The parameter values are reported in the figure, and $\delta_{l}$ is chosen relatively high so that it satisfies the conditions for the base case given in the appendix.
} 
The simplest way to characterize the extent to which an agent is financially constrained is by considering the agent's multiplier on his time 0 budget constraint, $\mu_{0}$ (bottom left panel). The multiplier $\mu_{0}$ can be interpreted as the value of or return on internal funds. For unconstrained agents $\mu_{0}=R$, since unconstrained agents simply save additional internal funds at the market interest rate, while for constrained agents $\mu_{0}>R$, that is, the return on internal funds exceeds the market interest rate. Since buying capital involves a larger payment up front, while leaving the agent with more funds at time 1 , agents who have a higher $\mu_{0}$, and therefore discount the additional funds at time 1 more heavily, may prefer leasing to buying.

Agents who are not financially constrained (i.e., whose collateral and repayment constraint are not binding) discount cash flows at the market interest rate $R$, own all their capital, and start the optimal size firm. The user cost of owned capital to financially unconstrained agents is $u_{b} \equiv 1-R^{-1}(1-\delta)<u_{l}$; they thus prefer to buy capital since leasing capital would separate ownership and control and imply a higher rate of depreciation without any benefit.

The model also predicts that there are some agents who have zero debt, despite the fact that they are financially constrained. These agents finance investment entirely with internal funds since there is an endogenous spread between borrowing and lending rates in our model due to the costly repossession; the borrowing rate for these agents is $\frac{R}{\pi(H)+\pi(L) \theta}>R$.

Our model focuses on the role of debt capacity, and only indirectly on the cost of bankruptcy. Indeed, in the model the leasing decision varies despite the fact that the probability of bankruptcy is constant. Thus, internal funds matter even controlling for the probability of bankruptcy. Nevertheless, the model also implies that as the probability of bankruptcy goes up (i.e., as $\pi(L)$ goes to 1), agents will never borrow, but instead either lease capital or finance it entirely with internal funds, since the high probability of low cash flow makes borrowing costly because repossession is likely.

\section{Empirical Predictions and Evidence}

\subsection{Empirical Predictions}

To summarize the empirical predictions of our model, we start with the predictions we have noted above and then define some additional financial variables in the model and discuss their relationship to leasing.

Above we showed that the fraction leased is decreasing in internal funds. The ratio of 
internal funds to capital increases in internal funds since the amount of capital financed externally is decreasing. The empirical implication is that measures of available internal funds (to assets), e.g., cash (to assets) and cash flow (to assets), should be negatively related to the fraction leased. Also, to the extent that outstanding debt reduces available internal funds, debt (to assets) should be positively related to the fraction leased. Thus we have the following empirical prediction:

Prediction 1 The fraction of capital leased decreases with available internal funds (to assets), and hence decreases with cash and cash flow (to assets), and increases with outstanding debt (to assets).

Note however that we showed that explicit debt incurred in financing the investment is non-monotone in internal funds, although total debt is monotonically decreasing in internal funds. Overall, caution is called for when investigating the relationship between leasing and debt.

Furthermore, the model predicts that the size of the firm is increasing in internal funds while the fraction of capital leased is decreasing in internal funds, which implies:

Prediction 2 The fraction of capital leased decreases with firm size.

In the model, only unconstrained firms would be willing to pay out dividends to the investor at time 0 , who in turn would use these funds to finance the leasing firms and financial intermediaries which provide the secured loans. ${ }^{21}$ We can thus define the dividends at time 0 as $\hat{d}_{0} \equiv \sum_{s \in S} \pi(s) \max \{-b(s), 0\}$, so that dividends are paid whenever the firm would otherwise be lending out funds. Since dividends to assets increase in internal funds we have:

Prediction 3 The fraction of capital leased decreases with dividends (to assets).

Finally, Tobin's $q$ is at times used as a measure of financial constraints since such constraints imply that the value of capital inside the firm exceeds its replacement cost. Define Tobin's $q$ as $q \equiv \frac{d_{0}+R^{-1} \sum_{s \in S} \pi(s) d_{1}(s)+(k-e)}{k}$, which corresponds to the present value reservation price per unit of capital that the agent requires to give up production and all capital. Due to the concavity of the production function, the marginal product of capital is decreasing, and so is the average product of capital at an optimum. The empirical implication of the model is hence that:

\footnotetext{
${ }^{21}$ In the analytical characterization in the appendix we set dividends at time 0 to zero. There we assume that the firms themselves lend these funds out, rather than returning them to investors at time 0 to lend out, but this is of course equivalent.
} 


\section{Prediction 4 The fraction of capital leased increases with Tobin's q.}

Our model hence predicts that leasing is related to several financial variables which are commonly used to measure financial constraints. ${ }^{22}$ We investigate these predictions empirically below.

\subsection{Data}

The two main data sources that we use are the 1992 Census of Manufactures micro data and Compustat. The Census of Manufactures (CM) is a survey of manufacturing plants conducted every five years. We aggregate the plant level data to the firm level and restrict our sample to firms which have at least one plant in the Annual Survey of Manufactures (ASM). ${ }^{23}$ The main data item from the CM that we use is "total rental payments," which is defined as "rental payments ... for use of such fixed assets as buildings, structures, and equipment." There are specific instructions regarding the treatment of leases which imply that payments on operating leases are included in this item while capital leases (as defined by the accounting rules) are excluded (and instead treated as if the capital was owned). Thus, total rental payments includes only true leases, which benefit from the preferential treatment in bankruptcy discussed above. Our leasing measures are complementary to measures using Compustat data, and we believe the Census data may more accurately measure rental payments for operating leases of fixed assets. In Compustat, there are two sources of data on operating leases: First, there is the reported rental expense, which includes operating lease expenses, but also includes payments for short term leases, contingent payments associated with capitalized lease obligations, and payments associated with non-fixed assets such as royalties. Second, there are footnote data on future rental expense commitments up to five years out. The rental commitment variable only includes noncancelable leases and has been shown to be a lower bound on actual rental expenses. ${ }^{24}$ The primary aim of the Census question on rental payments is to improve the measurement of the amount of capital deployed in each industry in order to improve the measurement of industry productivity, and this goal is exactly in line with our measurement objectives, unlike the objectives motivating accounting data. In addition, we

\footnotetext{
${ }^{22}$ See, e.g., Kaplan and Zingales (1997).

${ }^{23}$ The ASM is a rotating panel of plants consisting of all large plants (with 250 employees or more) as well as a sample of smaller plants. The sample is redrawn every five years and the panel starts two years after a CM, that is, in 1989 for plants in our sample. We restrict our sample in this way to ensure data quality.

${ }^{24}$ See Lim, Mann, and Mihov (2005); nevertheless, the related findings using Compustat lagged rental commitment data in Sharpe and Nguyen (1995) are consistent with our results using Census data.
} 
have data for "buildings \& other structures" and "machinery \& equipment" separately on rental payments, as well as on end of year assets, depreciation, and capital expenditures. Our data is also unique in providing rental payments data for smaller firms than available in Compustat and in providing data separately for structures and equipment. Finally, we have data on the number of employees and total value of shipments.

To investigate the relationship between the fraction of capital which is rented and financial variables we merge the Census data with Compustat using a Census-Compustat bridge file. The definitions and descriptive statistics of the Compustat variables that we use are summarized in Table $3 .^{25}$

\subsection{Empirical Evidence on Leased Capital}

We start by studying the fraction of capital which is rented as a function of size using Census data only. The benefit of using Census data only is that we are able to study the role of leasing across firms of all sizes, including very small firms, whereas the merged Census-Compustat data includes only publicly traded and hence much larger firms. The cost of using Census data only is that the only measure of the extent to which a firm is constrained is the size of the firm itself and we do not have explicit financial variables as in the merged data.

We use two measures of the fraction of capital which is rented. The first measures the fraction of capital services from leased capital by the ratio of rental payments to the sum of rental payments plus an estimate of the user cost of owned capital. ${ }^{26} \mathrm{We}$ estimate the user cost of owned capital as the sum of the estimated interest rate times the amount of owned capital plus depreciation. We use assets and depreciation from the Census data. We estimate the interest rate using the predicted values from a regression of the reported average interest rate on short term borrowings from Compustat on assets from Census data. We run this regression on the merged data and then use the estimated coefficients to predict interest rates for all firms in our data. ${ }^{27}$ The second measure is the

\footnotetext{
${ }^{25}$ In addition to Compustat variables, we use the estimates of the marginal tax rate before interest expense constructed by Graham (1996). We thank John Graham for kindly providing us with these estimates.

${ }^{26}$ Sharpe and Nguyen (1995) use this measure except that they use the minimum rental commitments due in 1 year (lagged by 1 year) from Compustat instead of rental payments. Our measure is analogous to the perpetuity measure of lease obligations which Lim, Mann, and Mihov (2005) show is the best predictor of future leasing expenses. In contrast, they argue that the measure in Graham, Lemmon, and Schallheim (1998), which uses the present value of lease commitments up to five years out, significantly underestimates leased capital, since lease commitments are a lower bound on obligations and do not account for lease renewals.

${ }^{27}$ Specifically, we first run the following regression on our merged Compustat/Census sample:
} 
ratio of rental payments to the sum of rental payments plus capital expenditures. The denominator is hence the total cash expenditures on rent and investment. This "cash flow" measure of the fraction of capital leased has the advantage that it involves neither asset size nor Compustat data directly. We will focus on the first measure, but will report some results for the second measure for this reason. ${ }^{28}$

Table 2 reports the average of these two measures across asset deciles in our data. In terms of the first measure, firms in the smallest decile rent more than $46 \%$ of their capital, whereas firms in the largest decile rent about $11 \%$ of capital on average, and the fraction rented is monotonically decreasing across size deciles. This is true for structures and equipment separately as well. Figure 2 shows the very strong relationship with size that emerges from the data graphically. The second measure behaves quite similarly. Leased capital is thus important for all firms, but is of particular importance for small firms. Indeed, it may be the most important source of external financing for very small firms. The fraction of capital leased is much higher for structures than for equipment. We might expect this given our model for two reasons: First, the costs of separating ownership and control might be higher for equipment since the moral hazard problem with respect to careful use and maintenance might be more severe for equipment, which might preclude leasing for some types of equipment. Second, since equipment on average depreciates faster, differences in the ability to repossess may be somewhat harder to detect, since the user cost of the first period is a larger fraction of the price. ${ }^{29}$ As a robustness check, we also scale the rental payments by the number of employees and by the total value of shipments and obtain similar results (see again Table 2). ${ }^{30}$

To summarize, we find that the fraction of capital rented decreases as the size of the firm increases and this relationship seems quantitatively important.

To study the relationship between the fraction of capital which is rented and mea-

(Compustat Item 105) $)_{i}=\alpha+\beta(\text { Census Assets })_{i}+\epsilon_{i}$. Then, we use the predicted interest rate $\hat{r}_{j}=\hat{\alpha}+\hat{\beta}$ (Census Assets) ${ }_{j}$ for the full sample.

${ }^{28}$ In unreported regressions, available by request, we also find similar results using sales as a measure of size and to scale the financial variables.

${ }^{29}$ For example, if the depreciation rate were $100 \%$, one would have to pay for the one period user cost of the equipment only even when buying (and not just when leasing the equipment), and there would be no difference.

${ }^{30} \mathrm{An}$ additional factor contributing to the relationship between size and leasing might be that all firms lease a relatively fixed amount of capital and hence leasing activity decreases with size. While we can not rule out that this mechanism is indeed at work, the fact that the same relationship obtains even within structures and equipment separately may alleviate this concern somewhat. Moreover, this relationship obtains even among Compustat firms, which are quite large and where this mechanism is hence unlikely to play an important role. Finally, we show below that there is a direct relationship between financial variables and leasing. 
sures of financial constraints we run regressions of our two leasing measures on financial variables using the merged Census-Compustat data. The results for regressions using capital overall are reported in Table 4. Panel A reports the results for the first measure, rental payments to total cost of capital services, and Panel B the results for the second measure, rental payments to sum of rental payments and capital expenditures. Note that all regressions include industry dummies at the two digit SIC code level, which are not reported. Thus, industry mean effects are accounted for. We estimate the relationship with OLS, but the results are similar when estimated with a Tobit regression accounting for left-censoring. ${ }^{31}$

The financial variables that we use are motivated by the empirical predictions of our model as well as by empirical studies such as Kaplan and Zingales (1997). We expect to find negative coefficients on size, dividends, cash flow, and cash, and positive coefficients on debt and $q$. As our model shows, variables which indicate that a firm is financially constrained, and places a high value on internal funds, should exhibit a positive correlation with the decision to lease.

Columns 1-6 report the results for each of the financial variables controlling for size, and for a multivariate regression including all financial variables. Dividends to assets is significantly negatively related to leasing, both controlling for size and in the multivariate specification. Payouts seem to be a relatively straightforward measure of the value of internal funds, and dividends to assets turns out to have the most robust relationship to leasing, more so even than size. Similarly, our most direct measure of available internal funds, cash flow to assets, is also significantly negatively related to leasing. On the other hand, long term debt to assets does not have a significant relationship to leasing in our sample. This is perhaps because, although long term debt decreases available internal funds which should increase leasing, our model also shows that debt and leasing can be substitute costly forms of finance and indeed in the model we find a non-monotonic relationship between financial constraints and explicit debt. ${ }^{32}$ Tobin's $q$ is not significant in the bivariate regression, but is significantly positively related to leasing in the multivariate specification where effects from variables potentially correlated with $q$ are accounted for. We expect a positive relationship between Tobin's $q$ and leasing since the value of constrained firms' capital exceeds the replacement cost. Finally, cash to assets is not significantly related to leasing in our sample. One reason why the cash variable

\footnotetext{
${ }^{31}$ Reported standard errors are robust to heteroscedasticity, and results are similar when clustering at the industry level is allowed for.

${ }^{32}$ Ang and Petersen (1984) study capital leases and find that firms with more book debt also have more capitalized leased assets. This may be because capital leases are more similar to true debt than operating leases are.
} 
may be problematic in this context is that leasing contracts at times require the lessee to hold minimum cash balances to cover lease payments. More importantly, while cash may constitute available internal funds, it may also represent net working capital which is held to fund operations. Moreover, as pointed out by Riddick and Whited (2006), constrained firms tend to hold larger cash balances to insure against future negative cash flow shocks. In the multivariate regression, size, dividends to assets, cash flow to assets, and $q$ all have a significant relation to the fraction of capital leased with the signs predicted by our theoretical model. The financial variables are also quantitatively important with a standard deviation increase in size, dividends, and cash flow reducing the fraction rented by approximately $3 \%, 2 \%$, and $1 \%$, respectively. Compared to a median fraction of rented capital of $12 \%$ this seems considerable. Moreover, since Compustat firms are relatively large, one might expect the relationship between financial variables and leasing to be even stronger for the Census firms for which financial characteristics are not observed.

\subsection{Robustness}

To control for the tax reasons for leasing we include a measure of the average tax rate and dummies for small and large tax loss carry forwards in the regression (column 7) and, alternatively, an estimate of the marginal tax rate before financing (column 8). ${ }^{33}$ The tax argument typically predicts that it is beneficial for low tax rate firms to lease and hence we would expect a negative coefficient on the tax rate variables and a positive coefficient on the tax loss dummies. None of the tax variables turn out to be significant here and three out of four estimates do not have the predicted sign. Thus, the support for the tax explanation is rather limited in our data. ${ }^{34}$ More importantly for our purposes, controlling for taxes does not significantly alter our results regarding the significance of the financial variables. Controlling for the marginal tax rate before financing actually strengthens our results somewhat: the coefficients on dividends and cash flow increase (in absolute value) and the cash variable has the predicted sign, although the estimate is still not significant. ${ }^{35}$

One might also argue that leasing is related to firms' desire and scope for operational

\footnotetext{
${ }^{33}$ For a detailed description of the variables see Table 3.

${ }^{34}$ One reason that our results on the effect of taxes differ from those in Graham, Lemmon, and Schallheim (1998) is that they recompute the marginal tax rates from Graham (1996) to account for the interest deduction from operating lease payments. Thus, their measure might be more precisely measured for firms with large rental expenses.

${ }^{35} \mathrm{We}$ recognize that several of the variables in our multivariate regressions may be collinear. We report F-statistics and the associated p-values for all regressions, and all are significant at the one percent level. However, the F-statistics do decrease as variables are added step-wise.
} 
flexibility. Since it is possible that leased capital can be more easily redeployed than owned capital, leasing may offer flexibility (see, e.g., Gavazza (2006a) for such an argument). This would suggest that measures of firms' desire for flexibility should raise the fraction of capital leased. Conversely, firms with more specific capital have less scope for flexibility or reversibility, and thus one expects firms with more specific capital to lease less. This might be because specific assets do not serve as good collateral, and are hence difficult to lease, or because specific assets give rise to more severe hold up problems, as argued by Klein, Crawford, and Alchian (1978). We use R\&D to sales ratios to measure how specific firms' capital is, with the idea that firms with more specific capital spend more on R\&D. We proxy for firms' needs for flexibility using information on the likelihood of low sales growth realizations and low cash flow realizations. ${ }^{36}$ We use two measures for each, the fraction of negative realizations for firm years up to 1992, and the fraction of firm year realizations up to 1992 which are less than the industry mean minus the industry standard deviation. We also control for firm age, since young firms in particular might require flexibility, although firm age may alternatively be interpreted as a measure of financial constraints. The results are in columns nine through eleven. Column nine shows that leasing is negatively related to expenditures on research and development, consistent with the idea that firms with more specific assets lease less. Column ten shows that leasing is significantly negatively related to firm age, and significantly positively related to the likelihood of negative cash flow realizations, while leasing is significantly negatively related to the likelihood of negative sales growth realizations. ${ }^{37}$ The positive sign on the likelihood of negative cash flow realizations is consistent with both the financial constraints explanation as well as the idea that leasing offers flexibility. The evidence regarding this alternative hypothesis, that leasing offers flexibility, is mixed however: while the sign on firm age is negative, which is consistent with the alternative hypothesis, the sign on the likelihood of negative sales growth is positive, which is not consistent with it. ${ }^{38}$ To account for the somewhat arbitrary cutoff at zero, column eleven reports similar results for the likelihood that sales growth and cash flow realizations are less than the industry mean minus the industry standard deviation. In this regression, of the

\footnotetext{
${ }^{36}$ See Petersen (1994) for a similar asymmetric measure of variability. He argues that it is downside variability which determines firms' desire for flexibility.

${ }^{37}$ In unreported results, we found that the fraction of leased capital was also significantly negatively related to the standard deviation of sales growth.

${ }^{38}$ In fact, since redeploying leased capital may require ex post renegotiation of long-term leases with the lessor, which is subject to ex post opportunistic behavior as in Klein, Crawford, and Alchian (1978), firms which are more likely to need to redeploy assets may in fact be less likely to lease. We leave a more detailed analysis of the circumstances under which leasing is more (or less) flexible than buying to future research.
} 
three flexibility variables, only the positive coefficient on the likelihood of low cash flows is significant. Finally, column twelve includes all financial, tax and flexibility variables together and shows that the low dividend firms, and firms with a higher likelihood of low cash flow realizations lease statistically significantly more. All other financial variables except long-term debt to assets have the expected sign, while the tax variable and R\&D to sales have the opposite sign to what one might expect when controlling for all financial and variability measures.

An alternative argument for why firms with higher variability of cash flows might lease more is a hedging argument. Firms might value leases as a way to transfer the risk of fluctuations in the value of the asset. Since firms which are financially constrained would value both the additional debt capacity due to the less costly repossession, as well as what may be for them a lower cost hedging strategy, it is difficult to distinguish these effects in our data. Either way, our results support a role for financial constraints in the lease vs. buy decision.

Panel B of Table 4 reports the results for the alternative dependent variable, rent over rent plus capital expenditures, with quite similar results. Size, dividends, and cash flow again have the predicted sign and are significant throughout. Both long-term debt and cash now have the predicted sign, but are only marginally significant when other financial variables are included. The marginal tax rate variable now has the predicted sign, but remains insignificant.

Table 5 reports the results for structures and equipment separately. We report the results for the first dependent variable, rent to total cost of capital services, only, since the results for the second dependent variable are comparable to those reported in Panel B of Table 4 for capital overall. Broadly speaking, the results are similar to the results for capital overall, although the results are weakened somewhat, at least for equipment. Size and dividends remain important, in particular in the regressions using data on structures. Tobin's $q$ remains significant with the predicted sign for structures as well, but the results for cash are more mixed. However, we might expect the effect of financial constraints to be harder to detect using data on equipment, since equipment typically has higher depreciation and since in addition it may not be possible to lease some types of equipment due to the severity of the moral hazard problem. The likelihood of low cash flow is again positively related to leasing, and significantly so for most specifications.

We conclude that there is a significant relationship between the fraction of capital leased or rented and financial variables, in particular size, dividends, cash flow, and the likelihood of low cash flow realizations, consistent with the predictions of our theory. This relationship seems largely robust to controlling for several alternative explanations and 
we find at best limited support for these alternatives. Additionally, in complementary empirical work using Compustat data only, Sharpe and Nguyen (1995) find that financial variables explain financial commitments to operating leases, but not capital leases using data from footnotes describing operating lease commitments. This supports the idea that it is precisely the lower cost of repossessing capital under operating leases which generates the empirical relationship between financial characteristics and the fraction of capital leased which we find.

\section{$5 \quad$ Related Literature}

\section{$5.1 \quad$ Theories of Leasing}

Several explanations for leasing have been suggested in the literature. The main focus of the finance literature is the tax reason for leasing. But it has also been suggested that leasing can increase market power, leasing can reduce adverse selection, leasing can reduce the transaction costs of redeploying capital, and that leasing may be part of an optimal portfolio choice problem.

Following Miller and Upton (1976), and Lewellen, Long, and McConnell (1976), the finance literature has focused on the analysis of the leasing decision in a Modigliani-Miller environment, where firms are indifferent between leasing and buying, except when facing different tax rates. ${ }^{39}$ Myers, Dill, and Bautista (1976) present a formula to evaluate the lease vs. buy decision in such an environment, which is now widely used. ${ }^{40}$ They show that differences in the tax rates across firms imply differences in the discount rate which may make it beneficial for low tax rate (and hence high discount rate) firms to lease, since the incremental cash flows of leasing are often positive early on and negative later on. Interestingly, the net gains to leasing decline as the fraction that firms can finance with debt when they buy declines, since the wedge between the discount rates declines. In contrast, in our model the net gains to leasing increase as the fraction that firms can finance with debt when they buy declines, since the difference between the debt capacity of leasing and secured lending increases.

Smith and Wakeman (1985) provide an informal list of characteristics of users and lessors which influence the leasing decision, explain many contractual provisions in leasing contracts, and discuss the repossession advantage of leasing informally. We are the first,

\footnotetext{
${ }^{39}$ Miller and Upton (1976) do however mention that there are differences between lessors and secured lenders in the ability to enforce their claim in two footnotes.

${ }^{40}$ See also McConnell and Schallheim (1983), who study the value of options embedded in lease contracts.
} 
to the best of our knowledge, to explicitly incorporate financial constraints into a model of the choice between leasing and secured lending. Wolfson (1985) studies the effect of risk sharing and incentive considerations on the lease-or-buy decision as well as the tradeoff between these considerations and the tax motive for leasing.

Sale-and-leaseback transactions are modeled by Kim, Lewellen, and McConnell (1978) as a way for stockholders to expropriate existing bondholders by issuing higher priority claims. In contrast, our theory suggests that these transactions may be an efficient, albeit costly, way to raise additional external funds, and thus offers a different interpretation of the results in the empirical literature on such transactions. ${ }^{41}$

Several additional explanations for leasing have been suggested in the literature. Leasing may allow a monopolist to extend his market power. Coase (1972) and Bulow (1986) argue that a durable goods monopolist may choose to lease goods to overcome the time inconsistency problem. Relatedly, Waldman (1997) and Hendel and Lizzeri (1999) argue that a durable goods monopolist may choose to lease in order to reduce the competition from used goods markets. ${ }^{42}$ The role of leasing in reducing adverse selection in the secondary market for durable goods has been considered by Hendel and Lizzeri (2002) and Johnson and Waldman (2003). ${ }^{43}$ Leasing can also economize on transactions costs. Flath (1980) suggests that short-term leasing is valuable because it economizes on the cost of transferring ownership, including the costs of assuring quality.

The rent vs. buy decision has been extensively studied in the housing literature, typically as a portfolio choice problem. ${ }^{44}$ Henderson and Ioannides (1983) consider a model where there is a moral hazard problem in utilization of rented housing which makes owning beneficial and distorts the portfolio choice problem. They assume that housing consumption is not an inferior good and find the counterfactual result that "higher wealth people will be renters" (p. 107) because their consumption demand exceeds their portfolio de-

\footnotetext{
${ }^{41}$ For example, Women's Wear Daily (April 20, 2005) reports that "A\&G has sold Asprey's Bond Street store to Quinlan Private, the Irish property group, ... A\&G Group said it planned to use the proceeds to fund its international expansion program. ... the current building has been handed back to A\&G Group on a long-term lease that will last for at least 25 years." Similarly, the Wall Street Journal (September 13, 2004) reports that "Krispy Kreme also gave details of a sale-leaseback deal ... saying it had sold six stores for $\$ 17.3$ million and agreed to lease them back for 20 years. The company had previously confirmed that some proceeds of the deal were used to fund continuing operations ... Some accounting experts said the sale-leaseback might be an indication of a cash crunch."

${ }^{42}$ See also Anderson and Ginsburgh (1994) for a related argument.

${ }^{43}$ See also Hendel, Lizzeri, and Siniscalchi (2005), who study optimal rental contracts which completely eliminate the adverse selection problem, and Johnson and Waldman (2004), who study leasing in a model with both adverse selection and moral hazard regarding maintenance.

${ }^{44}$ Risk sharing concerns have also been considered by Flath (1980) and Wolfson (1985).
} 
mand. Moreover, they find that the introduction of a borrowing constraint, where agents cannot borrow against future income for current consumption, cannot alter their general findings. Our model applied to the rent vs. buy decision for housing in contrast provides a simple explanation for why lower wealth, financially constrained households choose to rent. The effects of down payment requirements on the rent vs. buy decision have been studied, e.g., by Artle and Varaiya (1978), Stein (1995), and Engelhardt (1996). The models in this literature typically consider the choice of either renting or buying, whereas in our model agents can lease any fraction of their capital, i.e., the leasing decision is a convex problem.

The literature on trade credit provides arguments which may be the most closely related to our explanation for leasing. Frank and Maksimovic (1998) focus explicitly on the value of collateral in repossession and argue that a supplier is better able to capture the value of a repossessed input than a lender. Relatedly, Burkart and Ellingsen (2004) argue that it may be easier to keep a borrower from diverting inputs than from diverting cash and that hence a supplier may be able to lend more than a lender. Finally, Brennan, Maksimovic, and Zechner (1988) show that suppliers with market power may offer trade credit to be able to price discriminate.

\subsection{Empirical Literature on Leasing}

Graham, Lemmon, and Schallheim (1998) provide evidence supporting the hypothesis that low tax rate firms lease more. They also include financial variables and find that firms with lower Altman Z-scores, negative book value of common equity, and higher variability of earnings lease more.

The impact of financing constraints on the leasing decision is also the focus of two empirical studies. Krishnan and Moyer (1994) study capital leases and find that lessee firms have lower retained earnings relative to total assets, higher growth rates, lower coverage ratios, higher debt ratios, higher operating risk, and lower Altman Z-scores (i.e., higher bankruptcy potential) than non-lessee firms. ${ }^{45}$ Sharpe and Nguyen (1995) study both the capital lease share and the operating lease share of total capital costs and find that in particular the operating lease share is significantly higher for firms which pay no dividend, have lower earnings to sales, have lower credit ratings, and are smaller. The results in both these studies are broadly consistent with our findings and our model provides an explanation for the finding that it is specifically operating leases which are most affected by financial constraints. Operating leases are almost always true leases

\footnotetext{
${ }^{45}$ See Lasfer and Levis (1998) for related evidence using data on firms in the UK.
} 
from the vantage point of the law and hence enjoy a repossession advantage not shared by capital leases.

Ang and Peterson (1984) find a positive relationship between the lease to book value of equity and debt to book value of equity ratio in the data, but argue that theory in contrast suggests that debt and leases are substitutes. Hence they conclude that there is a leasing puzzle. However, Yan (2006) suggests that leases and debt may in fact be substitutes controlling for endogeneity problems and firm fixed effects. Lewis and Schallheim (1992) provide a resolution of the puzzle in an environment where leasing is motivated by tax considerations. They argue that leasing allows the transfer of tax shields which increases the benefits of debt financing for the lessee. An alternative resolution of the puzzle might be that constrained firms rely on both leasing and secured loans more heavily as sources of costly external finance.

In a study of sale-and-leaseback transactions, Slovin, Sushka, and Poloncheck (1990) find that such transactions are associated with positive abnormal returns to the lessees and conclude that this is due to a reduction in the present value of expected taxes induced by the transactions. However, this would also be consistent with the idea that financially constrained firms use sale-and-leaseback transactions to free up capital to take advantage of an investment opportunity, as the quote in footnote 41 above suggests. Ezzell and Vora (2001) also find positive abnormal returns associated with sale-and-leaseback transactions and moreover show that abnormal returns are higher for firms which do not pay dividends and which have lower interest coverage ratios, i.e., financially constrained firms. From the vantage point of our theory this suggests that the ability to raise additional external funds through sale-and-leaseback transactions may be particularly valuable for more credit constrained firms.

Gilligan (2004) provides empirical evidence on the role of leasing in reducing adverse selection in the secondary market for durable goods. Eisfeldt and Rampini (2006) document the importance of capital reallocation and Gavazza (2006a) studies aircraft leasing and finds evidence consistent with the hypothesis that lessors have a transaction cost advantage in redeploying capital and hence are capital reallocation intermediaries. Relatedly, Gavazza (2006b) studies the effect of measures of the liquidity of the secondary market for aircraft on the duration of aircraft leasing contracts. Sinai and Souleles (2005) provide a recent study of the rent vs. buy decision as a pure portfolio choice problem and consider a model with both rent and price risk. Finally, Petersen and Rajan (1997) and Burkart, Ellingsen, and Giannetti (2005) provide evidence that small and financially constrained firms use more trade credit. 


\section{Conclusions}

We argue that ownership affects the ability to repossess: It is easier for a lessor to repossess a leased asset from the lessee than it is for a secured lender to recover or foreclose on collateral. The repossession advantage of leasing in turn implies that a lessor is able to extend more credit against a leased asset than a secured lender can. Thus, leased capital has a higher debt capacity and leasing "preserves capital." However, allocating ownership to the agent who provides financing to facilitate repossession has a cost since it separates ownership and control. For more financially constrained agents the benefit of the higher debt capacity of leased capital outweighs the costs due to the agency problem induced by the separation of ownership and control. More financially constrained agents will hence lease a larger fraction of their capital than less constrained agents.

The law in the U.S., in particular the U.S. bankruptcy code, implies that a lessor has specific advantages over a secured lender in terms of the ability to regain control of an asset. However, we believe that it is probably the case in most legal environments that retaining ownership facilitates regaining control of an asset and thus enables increased implicit credit extension. Indeed, this advantage may be particularly important in environments with weak legal enforcement and thus leasing or renting capital may be more prevalent there. This is not a foregone conclusion, though, and how weak legal environments affect the relative merits of leasing and secured lending is open an empirical question. Moreover, there are specific differences in the relative advantage of leasing over secured lending across countries which suggest interesting testable implications; for example, in the U.K., recovery or foreclosure by a secured lender is much easier than in the U.S., and hence the relative advantage of leasing may be reduced. ${ }^{46}$ Similarly, it would be interesting to understand the relative prevalence of leasing vs. secured lending in economic history. This might furthermore shed light on the importance of the repossession and debt capacity incentives for leasing vis-à-vis the tax incentives.

The importance of financing constraints for leasing has implications for several key aspects of corporate finance. First, the fraction of the capital stock which is leased, in particular under operating leases, can be used as a revealed preference indicator of the extent to which a firm is financially constrained. This may be an important ingredient for indices of financial constraints and the appropriate data is available from Compustat. Second, in measuring leverage considering the implicit debt due to leasing seems critical

\footnotetext{
${ }^{46}$ The difference between the treatment of leasing and secured lending in the U.S. provides firms who need financing with a choice regarding the ability of a financier to repossess assets which may be valuable. Firms which are more constrained then choose to lease, which means they choose to issue tougher claims, while firms which prefer to issue weaker claims issue secured debt.
} 
since it is the more constrained firms which lease more. Third, in studies of firm investment, and specifically in studies of the effect of financing constraints on firm investment, attention should not be limited to capital expenditures but leased capital should also be considered. For example, ignoring leasing when measuring investment cash flow sensitivities to assess the effect of financial constraints may be misleading since financially constrained firms lease more capital and thus the investment cash flow sensitivities are mismeasured and are likely overstated. Finally, the higher debt capacity of leasing may be a particularly important reason to lease for small firms and new ventures, which are likely severely financially constrained. From a macroeconomic perspective, the fact that small firms lease about half their capital suggests that understanding leasing is critical for understanding the behavior of small firms, which have been argued to play a key role in determining business cycle fluctuations and economic growth. 


\section{Appendix}

This appendix provides the analytical characterization of the agent's problem stated in equations (2-6). The first order conditions of this problem are necessary and sufficient since the objective is linear and the constraint set convex. The Kuhn-Tucker multipliers are denoted by $\mu_{0}, \mu_{1}(s)$, $\lambda(s), \lambda_{r}(s), \bar{\xi}_{r}(s), \eta(H)$, and $\eta(L)$ on (7), (8), and (2) through (6), respectively, and by $\nu_{0}, \nu_{1}(s)$, $\xi_{l}, \xi_{b}$, and $\xi_{r}(s)$ on the non-negativity constraints on $d_{0}, d_{1}(s), i_{l}, i_{b}$, and $i_{b}^{r}(s)$, respectively. The first order conditions are, $\forall s \in \mathcal{S}$ :

$$
\begin{aligned}
1 & =\mu_{0}-\nu_{0} \\
\pi(s) & =\mu_{1}(s)-\nu_{1}(s) \\
\mu_{0} u_{l} & =\sum_{s \in \mathcal{S}}\left(\mu_{1}(s) a(s) \alpha k^{\alpha-1}+\lambda_{c}(s) a(s) \alpha k^{\alpha-1}\right)+\xi_{l} \\
\mu_{0}=\sum_{s \in \mathcal{S}}\left(\mu _ { 1 } ( s ) \left(a(s) \alpha k^{\alpha-1}\right.\right. & \left.+(1-\delta))+\lambda(s) \theta(1-\delta)+\lambda_{c}(s) a(s) \alpha k^{\alpha-1}+\bar{\xi}_{r}(s)\right)+\xi_{b} \\
\mu_{0} \pi(s) & =\mu_{1}(s) R+\lambda(s) R+\lambda_{c}(s) R+\eta(s) R-\eta\left(s^{\prime}\right) R, \quad s^{\prime} \neq s \\
\mu_{1}(H)(1-\delta)(1-\theta) & =\lambda_{c}(H) \theta(1-\delta)-\eta(H)(1-\delta)(1-\theta)+\underline{\xi}_{r}(H)-\bar{\xi}_{r}(H) \\
\mu_{1}(L)(1-\delta)(1-\theta) & =\lambda_{c}(L) \theta(1-\delta)+\eta(H)(1-\delta)(1-\theta)+\underline{\xi}_{r}(L)-\bar{\xi}_{r}(L) .
\end{aligned}
$$

The non-negativity constraints on dividends at time 1 are redundant since

$$
\begin{aligned}
d_{1}(s) & =a(s) k^{\alpha}+i_{b}(1-\delta)-i_{b}^{r}(1-\delta)(1-\theta)-R b(s) \\
& \geq a(s) k^{\alpha}+i_{b}(1-\delta)-i_{b}(1-\delta)(1-\theta)-\theta i_{b}(1-\delta) \geq a(s) k^{\alpha} \geq 0
\end{aligned}
$$

where we used the fact that the budget constraints hold with equality as well as equations (2) and (4). Since agents are required to collateralize promises, limited liability at time 1 is necessarily satisfied. Thus, $\mu_{1}(s)=\pi(s)$ and $\nu_{1}(s)=0, \forall s \in \mathcal{S}$, and we can disregard these constraints. Moreover, if $R>1$, the non-negativity constraint at time 0 binds, i.e., $d_{0}=0$, since summing (13) across states gives $\mu_{0}=R+\sum_{s \in \mathcal{S}}\left(\lambda(s)+\lambda_{r}(s)\right) R>1$ and hence $\nu_{0}>0$. We can hence disregard time 0 dividends.

Next we show that there will be no repossession in the high state, i.e., $i_{b}^{r}(H)=0$, since leasing dominates borrowing and letting capital be repossessed in both states. Suppose by contradiction that $i_{b}^{r}(H)>0$ and $\underline{\xi}_{r}(H)=0$. Then (14) implies that $\lambda_{r}(H)>0$, and (3) in state $H$ at equality implies that $b(H)>0$. Equation (5) and (3) then imply that $i_{b}^{r}(L)>0$. Consider increasing leased capital and decreasing owned capital as follows: $\mathrm{d} i_{l}=-\mathrm{d} i_{b}=-\mathrm{d} i_{b}^{r}(s)>0$ and $\mathrm{d} b(s)=R^{-1} \theta(1-\delta) \mathrm{d} i_{b}^{r}(s)$. This perturbation satisfies (2) through (6). Substituting into (7) yields $\mathrm{d} d_{0}=R^{-1}\left(\left(1-\delta_{l}\right)-\theta(1-\delta)\right) \mathrm{d} i_{l}>0$ given our assumption, and substituting into (8) yields $\mathrm{d} d_{1}(s)=0$. This contradicts the optimality of $i_{b}^{r}(H)>0$. Thus, we can disregard repossession in the high cash flow state.

The collateral constraint (2) in state $L$ is redundant, since it is implied by the repayment 
constraint (3) and the upper bound on repossession (4):

$$
R b(L) \leq a(L) k^{\alpha}+\theta i_{b}^{r}(L)(1-\delta)=i_{b}^{r}(L)(1-\delta) \leq \theta i_{b}(1-\delta) .
$$

Hence, we can set $\lambda(L)=0$ and disregard this constraint. Finally, given the assumption that $a(H) k^{\alpha}>\theta k(1-\delta)$, the repayment constraint (3) in state $H$ is slack and can be disregarded as well.

We will now provide a characterization of the solution. To measure how constrained an agent is consider the value of internal funds, i.e., the multiplier on the time 0 budget constraint, $\mu_{0}$. From above, $\mu_{0}=R\left(1+\lambda(H)+\lambda_{r}(L)\right)$. Agents with $\mu_{0}=R$ will lend and hence are unconstrained. Agents with $\mu_{0}>R$ are constrained and the higher $\mu_{0}$, the more constrained the agent. Recall also that the multipliers on the budget constraint at time 1 in state $s$ are $\mu_{1}(s)=\pi(s)$ and do not vary across agents. Thus, the extent of financial constraints can be appropriately measured by studying $\mu_{0}$ only. Also, taking internal funds at time 0 as the numeraire, agents discount cash flows at time 1 in state $s$ by $\pi(s) / \mu_{0}$ and thus unconstrained agents discount cash flows at $\pi(s) / R$, while constrained agents discount cash flows at a rate higher than that.

The details of the solution depend on the value of $\delta_{l}$ given the other parameters. In particular, for some $\delta_{l}$ some regions for $\mu_{0}$ collapse, because as $\delta_{l}$ decreases and leasing becomes more attractive, agents will no longer be as constrained when they substitute away from leased capital and fewer constraints will bind. Recall that given our assumptions $\delta_{l}$ is in the interval $(\delta, 1-\theta(1-\delta))$. The interval is partitioned into three subintervals, $\left(\delta, \bar{\delta}_{l}\right),\left(\bar{\delta}_{l}, \overline{\bar{\delta}}_{l}\right)$, and $\left(\overline{\bar{\delta}}_{l}, 1-\theta(1-\delta)\right)$, where $\delta<\bar{\delta}_{l}<\overline{\bar{\delta}}_{l}<1-\theta(1-\delta)$ and $\bar{\delta}_{l} \equiv 1-(\pi(H)+\pi(L) \theta)(1-\delta)$ and $\overline{\bar{\delta}}_{l} \equiv 1-(1+\pi(H)(1-\theta)) \theta(1-\delta)$.

The base case is the case where $\delta_{l} \in\left(\overline{\bar{\delta}}_{l}, 1-\theta(1-\delta)\right)$, i.e., where leasing is quite costly due to the higher depreciation. We discuss this case in a bit more detail first, and then briefly discuss the other two cases as well. Using the first order conditions, the following 3 critical levels of the value of internal funds can be derived: $\mu_{0}^{1} \equiv \frac{R \pi(H)(1-\theta)(1-\delta)}{1-\delta_{l}-\theta(1-\delta)}, \mu_{0}^{2}=\frac{R}{\theta}$, and $\mu_{0}^{3}=\frac{R}{\pi(H)+\pi(L) \theta}$. For $\delta_{l}$ in this interval, we have $\mu_{0}^{1}>\mu_{0}^{2}>\mu_{0}^{3}>R$.

Agents with the least internal funds lease all their capital and have a value of internal funds of $\mu_{0}=\frac{\pi(H) a(H) \alpha k^{\alpha-1}}{u_{l}}$ where $k=\frac{e}{u_{l}}$, so capital is increasing in this region. For agents with higher internal funds, this value reaches $\mu_{0}^{1}$. At that point, agents keep the amount of capital constant and substitute toward owned capital as $e$ increases. Moreover, agents borrow as much as they can against capital in both states of the world $b(s)=R^{-1} \theta i_{b}(1-\delta)$, which means that the collateral constraint binds and capital is fully repossessed in state $L$. This substitution requires additional internal funds at time 0 of $\left(1-R^{-1} \theta(1-\delta)\right)-\left(1-R^{-1}\left(1-\delta_{l}\right)\right)$ since the amount of internal funds required to buy a unit of capital exceeds the leasing fee, but leaves the agent at time 1 in state $H$ with the part of capital financed with internal funds, i.e., $(1-\theta)(1-\delta)$. Thus the expected return on this substitution is $\mu_{0}^{1} \equiv \frac{R \pi(H)(1-\theta)(1-\delta)}{1-\delta_{l}-\theta(1-\delta)}$.

Once leased capital $i_{l}$ reaches 0 , agents start to increase the total capital $k$ again, while con- 
tinuing to borrow as much as they can against it. The return on doing so is $\mu_{0}=\frac{\pi(H) a(H) \alpha k^{\alpha-1}+\pi(H)(1-\theta)(1-\delta)}{1-R^{-1} \theta(1-\delta)}$ where $k=\frac{e}{1-R^{-1} \theta(1-\delta)}$. The numerator in $\mu_{0}$ is the return from increasing owned capital, which is externally financed to the extent possible, and the denominator the cost of doing so.

When $\mu_{0}$ reaches $\mu_{0}^{2}$, agents keep $k$ constant again and start to reduce the amount that they borrow against state $L$. Agents can borrow $R^{-1} \pi(L) \theta$ per unit of capital repossessed in state $L$ and thus the expected return in this region is $\mu_{0}^{2}=\frac{R}{\theta}$. Agents can reduce borrowing against state $L$ only since in this region the incentive compatibility constraint (5) is slack; agents with high cash flow strictly prefer to repay $R b(H)$.

When the incentive compatibility constraint (5) starts to bind, agents increase $k$ again and continue to borrow as much as the collateral and incentive compatibility constraints allow. The value of internal funds is $\mu_{0}=\frac{\pi(H) a(H) \alpha k^{\alpha-1}+(1-\theta)(1-\delta)}{1-(\pi(H)+\pi(L) \theta) R^{-1} \theta(1-\delta)}$ and $k=\frac{e}{1-(\pi(H)+\pi(L) \theta) R^{-1} \theta(1-\delta)}$. The cost of external funds is $\frac{R}{\pi(H)+\pi(L) \theta}$ since a promise to pay in state $H$ has to be matched by an equal amount repossessed in state $L$ because of the incentive constraint, but the amount repossessed only frees up $\pi(L) \theta$ at time 0 due to the deadweight cost.

Once $\mu_{0}$ reaches $\mu_{0}^{3}=\frac{R}{\pi(H)+\pi(L) \theta}$, agents start to reduce the amount borrowed in an incentive compatible way while keeping $k$ constant, until borrowing reaches 0 . At that point, agents increase $k$ again but investment is fully internally financed, i.e., $\mu_{0}=\pi(H) a(H) \alpha k^{\alpha-1}+(1-\delta)$ and $k=e$. Once $\mu_{0}$ reaches $R$, agents keep $k$ fixed and start to save, i.e., are unconstrained.

For $\delta_{l} \in\left(\bar{\delta}_{l}, \overline{\bar{\delta}}_{l}\right)$, leasing is less costly in terms of depreciation than in the case just described. For low $e$, agents again lease all their capital. But when they substitute toward owned capital, they do not borrow so much that capital is fully repossessed in state $L$. Rather, the incentive compatibility constraint (5) binds, and $\overline{\bar{\mu}}_{0} \equiv \frac{R(1-\theta)(1-\delta)}{1-\delta_{l}-(\pi(H)+\pi(L) \theta) \theta(1-\delta)}$. Once leased capital reaches 0 , they again increase $k$ while borrowing as much as the collateral and incentive compatibility constraints allow. When $\mu_{0}$ reaches $\mu_{0}^{3}, k$ is again kept constant while borrowing is reduced until it reaches 0 . Then $k$ is increased using internal funds only until $\mu_{0}$ reaches $R$, when agents start to save. Thus, the characterization is the same except that there are only two critical levels of the value of internal funds, $\overline{\bar{\mu}}_{0}$ and $\mu_{0}^{3}$.

For $\delta_{l} \in\left(\delta, \bar{\delta}_{l}\right)$, leasing is even more beneficial which means that agents substitute toward owned capital only at a point where the value of internal funds is so low that they can fully internally finance the capital they buy. There is then only one critical level of $\mu_{0}, \bar{\mu}_{0} \equiv \frac{R(1-\delta)}{1-\delta_{l}}$, where agents substitute internally financed owned capital for leased capital. Once they own all their capital, they increase $k$ again until $\mu_{0}$ reaches $R$.

We now show how the partition of $(\delta, 1-\theta(1-\delta))$ into the three subintervals changes first as the probability of low cash flow, $\pi(L)$, varies, and then as the ability to repossess, $\theta$, varies.

As the probability of the low cash flow, and hence repossession, goes to $1, \lim _{\pi(L) \rightarrow 1} \bar{\delta}_{l}=$ $\lim _{\pi(L) \rightarrow 1} \overline{\bar{\delta}}_{l}=1-\theta(1-\delta)$, that is agents never borrow and instead finance all purchases of capital entirely with internal funds, for all $\delta_{l}$. The high probability of low cash flow makes borrowing costly since repossession is likely.

In contrast, as the probability of the low cash flow goes to $0, \lim _{\pi(L) \rightarrow 0} \bar{\delta}_{l}=\delta$ and $\lim _{\pi(L) \rightarrow 0} \overline{\bar{\delta}}_{l}=$ 
$1-(2-\theta) \theta(1-\delta)>\delta$, thus for all values of $\delta_{l}$, as agents substitute away from leased capital, they will either borrow such that all capital is repossessed in state $L$ or such that the collateral and incentive compatibility constraint bind.

As the ability to repossess $\theta$ goes to $0, \lim _{\theta \rightarrow 0} \bar{\delta}_{l}=1-\pi(H)(1-\delta)$ and $\lim _{\theta \rightarrow 0} \overline{\bar{\delta}}_{l}=1-\theta(1-\delta)$, thus capital will not be fully repossessed in state $L$ for any value of $\delta_{l}$. Repossession becomes too costly. Finally, as the ability to repossess goes to $1, \bar{\delta}_{l}, \overline{\bar{\delta}}_{l}$, and $1-\theta(1-\delta)$ all go to $\delta$. However, $\lim _{\theta \rightarrow 1} \frac{\overline{\bar{\delta}}_{l}-\bar{\delta}_{l}}{(1-\theta(1-\delta))-\bar{\delta}_{l}}=0$, that is, as agents substitute away from leased capital, they will either borrow such that all capital is repossessed in state $L$ or finance purchases internally. 


\section{References}

Abel, A. B., and J. C. Eberly, 1994, "A Unified Model of Investment under Uncertainty," American Economic Review 84, 1369-1384.

Alchian, A., and H. Demsetz, 1972, "Production, Information Costs, and Economic Organization," American Economic Review, 62, 777- 795

Anderson, S. P., and V. A. Ginsburgh, 1994, "Price Discrimination via Second-hand Markets," European Economic Review, 38, 23-44.

Andrew, G. M., and D. J. Gilstad, 2005, "A Generation of Bias against Leasing," Journal of Equipment Lease Financing, 23 (2).

Ang, J., and P. P. Peterson, 1984, "The Leasing Puzzle," Journal of Finance, 39, 10551065.

Artle, R., and P. Varaiya, 1978, "Life Cycle Consumption and Home Ownership," Journal of Economic Theory, 18, 38-58.

Ayer, J. D., and M. L. Bernstein, 2002, Bankruptcy in Practice, American Bankruptcy Institute, Alexandria.

Ayer, J. D., M. L. Bernstein, and J. Friedland, 2003, "What Every Secured Creditor (and its Lawyer) Should Know about Chapter 11," American Bankruptcy Institute Journal, $22(9)$.

Ayer, J. D., M. L. Bernstein, and J. Friedland, 2004a, "Bankruptcy Issues for Landlords and Tenants," American Bankruptcy Institute Journal, 23 (8).

Ayer, J. D., M. L. Bernstein, and J. Friedland, 2004b, "Executory Contracts under $\S 365$," American Bankruptcy Institute Journal, 23 (9).

Ayotte, K. M., and S. Gaon, 2005, "Asset-backed Securities: Costs and Benefits of 'Bankruptcy Remoteness'," Working Paper, Columbia Business School.

Benmelech, E., and N. K. Bergman, 2006, "Liquidation Values and the Credibility of Financial Contract Renegotiation: Evidence from U.S. Airlines," Working Paper, Harvard University and MIT.

Brealey, R. A., S. C. Myers, and F. Allen, 2005," Principles of Corporate Finance, 8th Edition, McGraw-Hill, New York.

Brennan, M. J., V. Maksimovic, and J. Zechner, 1988, "Vendor Financing," Journal of Finance, 43, 1127-1141.

Bulow, J., 1986, "An Economic Theory of Planned Obsolescence," Quarterly Journal of Economics, 101, 729-749. 
Burkart, M., and T. Ellingsen, 2004, "In-kind Finance: A Theory of Trade Credit," American Economic Review, 94, 569-590.

Burkart, M., T. Ellingsen, and M. Giannetti, 2005, "What you Sell is what you Lend? Explaining Trade Credit Contracts," Working Paper, Stockholm School of Economics.

Califano, P. C., 2002, "Lessors' Enforcement Rights under Sec. 365(d)(10) of the Bankruptcy Code," Journal of Equipment Lease Financing, 20 (1), 10-17.

Coase, R. H. 1972, "Durability and Monopoly," Journal of Law and Economics, 15, 143-149.

Diamond, D. W., 1984, "Financial Intermediation and Delegated Monitoring," Review of Economic Studies, 51, 393-414.

Eisfeldt, A. L., and A. A. Rampini, 2006, "Capital Reallocation and Liquidity," Journal of Monetary Economics, 53, 369-399.

Eisfeldt, A. L., and A. A. Rampini, 2007, "New or Used? Investment with Credit Constraints," Journal of Monetary Economics, forthcoming.

Engelhardt, G. V., 1996, "Consumption, Down Payments, and Liquidity Constraints," Journal of Money, Credit, and Banking, 28, 255-271.

Ezzell, J. R., and P. P. Vora, 2001, "Leasing versus Purchasing: Direct Evidence on a Corporation's Motivations for Leasing and Consequences of Leasing," Quarterly Review of Economics and Finance, 41, 33-47.

Fazzari, S., R. Glenn Hubbard, and B. Petersen, 1988, "Finance Constraints and Corporate Investment," Brookings Papers on Economic Activity 1, 141-195.

Flath, D., 1980, "The Economics of Short-term Leasing," Economic Inquiry, 18, 247-259.

Frank, M., and V. Maksimovic, 1998, "Trade Credit, Collateral, and Adverse Selection," Working Paper, University of British Columbia and University of Maryland.

Gavazza, A., 2006a, "Leasing and Secondary Markets: Theory and Evidence from Commercial Aircraft," Working Paper, Yale University.

Gavazza, A., 2006b, "Asset Liquidity, Boundaries of the Firm and Financial Contracts: Evidence from Aircraft Leases," Working Paper, Yale University.

Gilligan, T. W., 2004, "Lemons and Leases in the Used Business Aircraft Market," Journal of Political Economy, 112, 1157-1180.

Graham, J. R., 1996, "Debt and the Marginal Tax Rate," Journal of Financial Economics, 41, 41-73.

Graham, J. R., M. L. Lemmon, and J. S. Schallheim, 1998, "Debt, Leases, Taxes, and the Endogeneity of Corporate Tax Status," Journal of Finance, 53, 131- 162. 
Hart, O., and J. Moore, 1994, "A Theory of Debt Based on the Inalienability of Human Capital," Quarterly Journal of Economics, 109, 841-879.

Hendel, I., and A. Lizzeri, 1999, "Interfering with Secondary Markets," RAND Journal of Economics, 30, 1-21.

Hendel, I., and A. Lizzeri, 2002, "The Role of Leasing under Adverse Selection," Journal of Political Economy, 110, 113-143.

Hendel, I., A. Lizzeri, and M. Siniscalchi, 2005, "Efficient Sorting in a Dynamic Adverseselection Model," Review of Economic Studies, 72, 467-497.

Henderson, J. V., and Y. M. Ioannides, 1983, "A Model of Housing Tenure Choice," American Economic Review, 73, 98-113.

Johnson, J. P., and M. Waldman, 2003, "Leasing, Lemons, and Buy-backs," RAND Journal of Economics, 34, 247-265.

Johnson, J. P., and M. Waldman, 2004, "Leasing, Lemons, and Moral Hazard," Working Paper, Cornell University.

Kaplan, S. N., and L. Zingales, 1997, "Do Investment-cash Flow Sensitivities Provide Useful Measures of Financing Constraints?" Quarterly Journal of Economics, 112, 169-215.

Kim, E. H., W. G. Lewellen, and J. J. McConnell, 1978, "Sale-and-leaseback Agreements and Enterprise Valuation," Journal of Financial and Quantitative Analysis, 13, 871881.

Kiyotaki, N., and J. Moore, 1997, "Credit Cycles," Journal of Political Economy, 105, 211-248.

Klein, B., R. G. Crawford, and A. A. Alchian, 1978, "Vertical Integration, Appropriable Rents, and the Competitive Contracting Process," Journal of Law and Economics, 21, 297-326.

Krishnan, V. S., and R. C. Moyer, 1994, "Bankruptcy Costs and the Financial Leasing Decision," Financial Management, 23 (2), 31-42.

Lacker, J. M., 2001, "Collateralized Debt as the Optimal Contract," Review of Economic Dynamics, 4, 842-859.

Lasfer, M. A., and M. Levis, 1998, "The Determinants of the Leasing Decision of Small and Large Companies," European Financial Management, 4, 159-184.

Lewellen, W. G., M. S. Long, and John J. McConnell, 1976, "Asset Leasing in Competitive Capital Markets," Journal of Finance, 31, 787-798.

Lewis, C., and J. Schallheim, 1992, "Are Debt and Leases Substitutes?" Journal of Financial and Quantitative Analysis, 27, 497-511. 
Lim, S. C., S. C. Mann, and V. T. Mihov, 2005, "Market Evaluation of Off-Balance Sheet Financing: You Can Run but You Can't Hide," Working Paper, Texas Christian University.

Mayer, D. G., 2005, "True Leases under Attack: Lessors Face Persistent Challenges to True Lease Transactions," Journal of Equipment Lease Financing, 23 (3 Part B), $1-25$.

McConnell, J. J., and J. S. Schallheim, 1983, "Valuation of Asset Leasing Contracts," Journal of Financial Economics, 12, 237-262.

Miller, M. , and C. Upton, 1976, "Leasing, Buying, and the Cost of Capital Services," Journal of Finance, 31, 761-786.

Myers, S. C., D. A. Dill, and A. J. Bautista, 1976, "Valuation of Financial Lease Contracts," Journal of Finance, 31, 799-819.

Nöldeke, G., and K. M. Schmidt, 1998, "Sequential Investments and Options to Own," RAND Journal of Economics, 29, 633-653.

Petersen, M. A., 1994, "Cash Flow Variability and Firms Pension Choice: A Role for Operating Leverage," Journal of Financial Economics, 36, 361- 383.

Petersen, M. A., and Raghuram Rajan, 1997, "Trade Credit: Theory and Evidence," Review of Financial Studies, 10, 661-691.

Rampini, A. A., 2005, "Default and Aggregate Income," Journal of Economic Theory, $122,225-253$.

Riddick, L., and T. M. Whited, 2006, "The Corporate Propensity to Save," Working Paper, American University and University of Wisconsin.

Ross, S. A., R. W. Westerfield, and J. F. Jaffe, 2002, Corporate Finance, 6th Edition, McGraw-Hill, New York.

Schallheim, J. S., 1994, Lease or Buy? Principles of Sound Decision Making, Harvard Business School Press, Boston.

Sharpe, S. A., and H. H. Nguyen, 1995, "Capital Market Imperfections and the Incentive to Lease," Journal of Financial Economics, 39, 271-294.

Sinai, T., and N. S. Souleles, 2005, "Owner-occupied Housing as a Hedge against Rent Risk," Quarterly Journal of Economics, 120, 763-789.

Slovin, M. B., M. E. Sushka, and J. A. Poloncheck, 1990, "Corporate Sale-and-leasebacks and Shareholder Wealth," Journal of Finance, 45, 289-299.

Smith, C. W., Jr., and L. M. Wakeman, 1985, "Determinants of Corporate Leasing Policy," Journal of Finance, 40, 895-908. 
Stein, J., 1995, "Prices and Trading Volume in the Housing Market: A Model with Down-payment Constraints," Quarterly Journal of Economics, 110, 379-406.

Stulz, R. M., and H. Johnson, 1985, "An Analysis of Secured Debt," Journal of Financial Economics, 14, 501-521.

Waldman, M., 1997, "Eliminating the Market for Secondhand Goods: An Alternative Explanation for Leasing," Journal of Law and Economics, 40, 6192.

Wolfson, M. A., 1985, "Tax, Inventive, and Risk-sharing Issues in the Allocation of Property Rights: The Generalized Lease-or-buy Problem," Journal of Business, 58, 159-171.

Yan, A., 2006, "Leasing and Debt Financing: Substitutes or Complements?" Journal of Financial and Quantitative Analysis, 41, 709-731. 


\section{Table 1: Types of Leases: Law, Taxation, and Accounting}

\section{Bankruptcy Law and Commercial Law}

Bankruptcy Code, Chapter 11, §361-363, and §365; U.C.C. §1-201 (37).

\section{True Lease}

- Executory contract: Contractual obligations of both parties largely remain to be performed.

- Lessor retains effective ownership.

- In Chapter 11, lessee can assume the lease (and continue to make payments) or reject the lease (and return asset).
Lease Intended as Security

- Lessor has merely security interest.

Lessee acquires effective ownership.

In Chapter 11, lease is recharacterized as secured credit and asset is subject to automatic stay which prohibits recovery of or foreclosure on collateral.

Criteria for Security Interest Lease not subject to termination and

(1) Lease duration exceeds remaining economic life.

(2) Lessee bound to renew lease for remaining life or bound to become owner.

(3) Lessee has option to renew lease for remaining life for no additional (or nominal) consideration.

(4) Lessee has option to become owner for no additional (or nominal) consideration.

\section{Taxation}

Revenue Procedure 2001-28.

\section{True Lease}

- Lessee expenses rental payments.

- Lessor treats asset as capital expenditure (with associated depreciation) and rental payments as income.

\section{Conditional Sales Contract}

Lease treated like term loan or installment purchase contract.

- Lessee treats asset as capital expenditure (with associated depreciation) and deducts implicit interest.

Criteria for True Lease (Meeting all criteria is required. Focus is on intent.)

(1) Minimum "at risk" investment: Lessor's investment exceeds $20 \%$ at all times. Remaining life of asset exceeds $20 \%$ of economic life. Residual value of asset exceeds $20 \%$ of original value.

(2) No bargain purchase option when lease expires. Lessor has no option to sell.

(3) Limits on investments (improvements, modifications, and additions) by lessee.

(4) No lessee loans or guarantees to lessor.

(5) Profit requirement: Lessor expects profits.

\section{Accounting}

SFAS No. 13, "Accounting for Leases."

\section{Operating Lease}

- Lease does not substantially transfer risks and benefits of ownership to lessee.

- Lease off balance sheet.

- Lessee discloses future minimum rental payments in aggregate and for each of next 5 years in footnotes.

\section{Capital Lease}

- Lease on balance sheet.

Lessee capitalizes leased asset and records corresponding debt obligation on balance sheet.

Criteria for Capital Lease (Meeting one criterion is sufficient.)

(1) Transfer of ownership before the end of lease term without additional compensation.

(2) Bargain purchase option (option to buy at price sufficiently below value at exercise date) when lease expires.

(3) Lease term exceeds $75 \%$ of economic life.

(4) Lease payments exceed $90 \%$ of asset's value in present value. 


\section{Table 2: Ratio of Rental Payments to Measures of Total Capital and Firm Size Across Asset Deciles}

The table describes the ratio of rental payments to various measures of total capital and firm size across asset deciles. We use the 1992 Census of Manufactures micro data which includes data on rental payments (which includes payments made on operating leases), end of year assets, depreciation, and capital expenditures for both "buildings and other structures" and "machinery and equipment," as well as employment and total value of shipments. We aggregate the plant level data to firm level data and restrict the sample to firms which have at least one plant which is part of the Annual Survey of Manufactures. We use the end of year assets as our measure of size in determining the deciles. There are 37,730 observations in our data. We compute the various ratios as the average of the ratios for all firms in each size decile. We also report the lower cutoffs for each decile. The interest rate is the predicted value using coefficients estimated in a regression of the average interest rate on short-term borrowing (Compustat Item 105) on assets from Census in merged Census-Compustat data.

\begin{tabular}{|c|c|c|c|c|c|c|c|c|c|c|}
\hline Variable & $1 \mathrm{st}$ & $2 \mathrm{nd}$ & $3 \mathrm{rd}$ & 4 th & 5 th & 6 th & 7 th & 8 th & 9th & 10th \\
\hline \multicolumn{11}{|c|}{ Rent to Total Cost of Capital Services $\left(\frac{\text { rent }}{r e n t+r \% \times a s s e t s+\text { depreciation }}\right)$} \\
\hline Total & $46.64 \%$ & $38.18 \%$ & $32.04 \%$ & $28.62 \%$ & $27.09 \%$ & $23.21 \%$ & $20.70 \%$ & $17.61 \%$ & $14.81 \%$ & $10.65 \%$ \\
\hline Structures & $74.76 \%$ & $69.93 \%$ & $65.01 \%$ & $61.21 \%$ & $56.68 \%$ & $51.42 \%$ & $45.18 \%$ & $39.49 \%$ & $32.87 \%$ & $23.28 \%$ \\
\hline Equipment & $20.66 \%$ & $15.38 \%$ & $12.22 \%$ & $10.83 \%$ & $10.35 \%$ & $8.38 \%$ & $8.30 \%$ & $7.42 \%$ & $7.16 \%$ & $5.93 \%$ \\
\hline \multicolumn{11}{|c|}{ Rent to Sum of Rent and Capital Expenditures $\left(\frac{\text { rent }}{\text { rent }+ \text { capital expenditures }}\right)$} \\
\hline Total & $51.38 \%$ & $46.92 \%$ & $42.98 \%$ & $41.45 \%$ & $41.10 \%$ & $37.76 \%$ & $34.22 \%$ & $30.31 \%$ & $25.05 \%$ & $18.30 \%$ \\
\hline Structures & $43.97 \%$ & $40.57 \%$ & $35.92 \%$ & $37.21 \%$ & $37.21 \%$ & $37.40 \%$ & $34.43 \%$ & $33.19 \%$ & $29.08 \%$ & $23.68 \%$ \\
\hline Equipment & $25.48 \%$ & $22.03 \%$ & $20.21 \%$ & $20.08 \%$ & $19.54 \%$ & $17.58 \%$ & $17.61 \%$ & $17.65 \%$ & $17.82 \%$ & $15.05 \%$ \\
\hline \multicolumn{11}{|c|}{ Rent to Employment $\left(\frac{\text { rent }}{\text { number of empolyees }}\right)$ (in thousands) } \\
\hline Total & 1.986 & 2.075 & 1.857 & 1.875 & 1.925 & 1.781 & 1.675 & 1.552 & 1.445 & 1.291 \\
\hline Structures & 1.347 & 1.387 & 1.323 & 1.314 & 1.356 & 1.252 & 1.178 & 1.046 & 0.915 & 0.678 \\
\hline Equipment & 0.639 & 0.688 & 0.534 & 0.561 & 0.568 & 0.528 & 0.491 & 0.496 & 0.523 & 0.558 \\
\hline \multicolumn{11}{|c|}{ Rent to Total Shipments $\left(\frac{\text { rent }}{\text { total value of shipments }}\right)$} \\
\hline Total & $2.92 \%$ & $2.63 \%$ & $2.18 \%$ & $2.18 \%$ & $2.09 \%$ & $1.65 \%$ & $1.47 \%$ & $1.35 \%$ & $1.12 \%$ & $0.75 \%$ \\
\hline Structures & $1.87 \%$ & $1.74 \%$ & $1.51 \%$ & $1.47 \%$ & $1.37 \%$ & $1.18 \%$ & $1.05 \%$ & $0.88 \%$ & $0.74 \%$ & $0.40 \%$ \\
\hline Equipment & $1.05 \%$ & $0.89 \%$ & $0.67 \%$ & $0.70 \%$ & $0.72 \%$ & $0.47 \%$ & $0.42 \%$ & $0.47 \%$ & $0.38 \%$ & $0.32 \%$ \\
\hline \multicolumn{11}{|c|}{ Decile Cutoff (millions) } \\
\hline & 0 & 0.08 & 0.18 & 0.34 & 0.64 & 1.2 & 2.2 & 4.1 & 8.1 & 21 \\
\hline
\end{tabular}




\section{Table 3: Descriptive Statistics}

The table shows the descriptive statistics for the variables used in the regressions of the fraction of capital services rented on various financial and control variables. Data is micro data from a cross section of manufacturing plants from the 1992 Census of Manufactures for the dependent variable (aggregated to the firm level), firm age, and the industry dummies, and from Compustat for financial and tax variables and the standard deviation of sales growth. See Table 2 for the details of the construction of the dependent variables using Census data. Assets are Item 6 (Assets - Total/Liabilities and Stockholders' Equity - Total); dividends are Item 21 (Dividends - Common) plus (where available) Item 19 (Dividends - Preferred); long-term debt is Item 9 (Long-Term Debt - Total); cash flow is Item 18 (Income Before Extraordinary Items) plus Item 14 (Depreciation and Amortization); Tobin's $q$ is Item 6 plus Item 24 (Price - Close) times Item 25 (Common Shares Outstanding) minus Item 60 (Common Equity - Total) minus Item 74 (Deferred Taxes - Balance Sheet) all divided by Item 6; cash is Item 1 (Cash and ShortTerm Investments). The average tax rate is Item 16 (Income Taxes) divided by the sum of Item 16 and Item 18, zero if Item 16 is negative, and one if Item 16 is positive and Item 18 negative. The marginal tax rate is the before interest expense marginal tax rate constructed by John Graham (see, e.g., Graham, Lemmon, and Schallheim (1998)). The small (large) tax loss dummy is an indicator variable which is one when Item 52 (Net Operating Loss Carry Forward) is positive and smaller (larger) than the sum of Item 18, Item 14, Item 16, and Item 15 (Interest Expense). R\&D to sales is Item 46 divided by Item 12. The firm age variable is the age of the firm according to Census data. The $\%$ of negative sales growth and cash flow variables are the fraction of firm year observations with negative values up to year 1992. The $\%$ of sales growth and cash flow less than $\mu_{i n d}-\sigma_{\text {ind }}$ are the fraction of firm year observations with values less than the industry mean minus the industry standard deviation up to year 1992. The industry dummies are the industry of the largest plant of a firm measured by the value of shipments.

\begin{tabular}{|c|c|c|c|c|c|}
\hline Dependent Variables & & Observations & Mean & Std. Dev. & Median \\
\hline $\begin{array}{l}\text { rental pmts. } \\
\text { rental pmts }+r \% \times \text { assets }+ \text { depr }\end{array}$ & Overall & 1649 & $16.35 \%$ & $15.74 \%$ & $12 \%$ \\
\hline & Equipment & 1649 & $7.86 \%$ & $10.12 \%$ & $4.5 \%$ \\
\hline & Structures & 1637 & $33.77 \%$ & $28.89 \%$ & $25 \%$ \\
\hline$\frac{\text { rental pmts. }}{\text { rental pmts. }+ \text { cap. ex }}$ & Overall & 1625 & $24.01 \%$ & $21.30 \%$ & $19 \%$ \\
\hline & Equipment & 1366 & $17.09 \%$ & $21.23 \%$ & $8.8 \%$ \\
\hline & Structures & 1317 & $35.66 \%$ & $32.03 \%$ & $25 \%$ \\
\hline Independent Variables & & & & & \\
\hline $\log ($ assets $)$ & & 1649 & 5.26 & 2.03 & 5.1 \\
\hline$\frac{\text { dividends }}{\text { assets }}$ & & 1649 & $1.28 \%$ & $2.00 \%$ & $0.40 \%$ \\
\hline$\frac{\text { long-term debt }}{\text { assets }}$ & & 1649 & $19.15 \%$ & $17.95 \%$ & $15 \%$ \\
\hline$\frac{\text { cash flow }}{\text { assets }}$ & & 1637 & $6.27 \%$ & $11.99 \%$ & $8.3 \%$ \\
\hline$q$ & & 1507 & 1.67 & 1.11 & 1.30 \\
\hline$\frac{\text { cash }}{\text { assets }}$ & & 1649 & $10.40 \%$ & $12.86 \%$ & $5.2 \%$ \\
\hline Average tax rate & & 1648 & $33.73 \%$ & $26.41 \%$ & $36 \%$ \\
\hline Marginal tax rate & & 1364 & $30.17 \%$ & $7.85 \%$ & $34 \%$ \\
\hline Small tax loss dummy & & 1649 & 0.10 & 0.31 & 0 \\
\hline Large tax loss dummy & & 1649 & 0.19 & 0.39 & 0 \\
\hline$\frac{\mathrm{R} \& \mathrm{D}}{\text { sales }}$ & & 1532 & $3.94 \%$ & $9.28 \%$ & $0.99 \%$ \\
\hline Firm age & & 1062 & 13.91 & 4.07 & 16 \\
\hline$\%$ negative sales growth & & 1463 & $23.45 \%$ & $16.34 \%$ & $21.88 \%$ \\
\hline$\%$ negative cash flow & & 1517 & $10.76 \%$ & $18.84 \%$ & 0 \\
\hline$\%$ sales growth $<\mu_{i n d}-\sigma_{i n d}$ & & 1463 & $10.28 \%$ & $11.82 \%$ & $6.67 \%$ \\
\hline$\%$ cash flow $<\mu_{i n d}-\sigma_{i n d}$ & & 1517 & $10.53 \%$ & $18.88 \%$ & 0 \\
\hline
\end{tabular}


Table 4: Regression Results: Fraction of Capital Services Rented for Capital Overall

The table shows the coefficients of regressions of two measures of the fraction of capital services rented for capital overall on various financial and control variables (controlling for industry dummies at the two digit SIC code level). Heteroscedasticity corrected standard errors are in parenthesis. Data is micro data from a cross section of firms from the 1992 Census of Manufactures for the dependent variables, firm age, and the industry dummies, and from Compustat for financial variables, tax variables, and the standard deviation of sales growth. For a detailed definition of the variables see the description in Table 3 . Statistical significance at the $1 \%, 5 \%$, and $10 \%$ level is indicated by ${ }^{* * *}$, ${ }^{* *}$, and ${ }^{*}$, respectively.

Panel A: Dependent Variable: Rental Payments / (Rental Payments $+r \% \times$ Assets + Depreciation)

\begin{tabular}{|c|c|c|c|c|c|c|c|c|c|c|c|c|}
\hline Regression & 1 & 2 & 3 & 4 & 5 & 6 & 7 & 8 & 9 & 10 & 11 & 12 \\
\hline $\log ($ assets $)$ & $\begin{array}{l}-0.0131^{* * *} \\
(0.0022)\end{array}$ & $\begin{array}{l}-0.0148^{* * *} \\
(0.0021)\end{array}$ & $\begin{array}{l}-0.0146^{* * *} \\
(0.0021)\end{array}$ & $\begin{array}{l}-0.0150^{* * *} \\
(0.0022)\end{array}$ & $\begin{array}{l}-0.0145^{* * *} \\
(0.0021)\end{array}$ & $\begin{array}{l}-0.0123^{* * *} \\
(0.0024)\end{array}$ & $\begin{array}{l}-0.0120^{* * *} \\
(0.0025)\end{array}$ & $\begin{array}{l}-0.0103^{* * *} \\
(0.0025)\end{array}$ & $\begin{array}{l}-0.0123^{* * *} \\
(0.0025)\end{array}$ & $\begin{array}{l}-0.0076^{* *} \\
(0.0032)\end{array}$ & $\begin{array}{l}-0.0051 \\
(0.0032)\end{array}$ & $\begin{array}{l}-0.0053 \\
(0.0036)\end{array}$ \\
\hline$\frac{\text { dividends }}{\text { assets }}$ & $\begin{array}{l}-0.8405^{* * *} \\
(0.2196)\end{array}$ & & & & & $\begin{array}{l}-0.9029^{* * *} \\
(0.2583)\end{array}$ & $\begin{array}{l}-0.8879^{* * *} \\
(0.2574)\end{array}$ & $\begin{array}{l}-1.2155^{* * *} \\
(0.2155)\end{array}$ & $\begin{array}{l}-0.8546^{* * *} \\
(0.2812)\end{array}$ & $\begin{array}{l}-0.7293^{* * *} \\
(0.2788)\end{array}$ & $\begin{array}{l}-0.6572^{* *} \\
(0.2866)\end{array}$ & $\begin{array}{l}-0.8265^{* * *} \\
(0.2948)\end{array}$ \\
\hline$\frac{\text { long-term debt }}{\text { assets }}$ & & $\begin{array}{l}-0.0050 \\
(0.0207)\end{array}$ & & & & $\begin{array}{l}-0.0051 \\
(0.0260)\end{array}$ & $\begin{array}{l}-0.0050 \\
(0.0260)\end{array}$ & $\begin{array}{l}-0.0311 \\
(0.0277)\end{array}$ & $\begin{array}{l}-0.0100 \\
(0.0270)\end{array}$ & $\begin{array}{l}0.0249 \\
(0.0301)\end{array}$ & $\begin{array}{l}0.0138 \\
(0.0296)\end{array}$ & $\begin{array}{l}-0.0001 \\
(0.0344)\end{array}$ \\
\hline$\frac{\text { cash flow }}{\text { assets }}$ & & & $\begin{array}{l}-0.0891^{* *} \\
(0.0370)\end{array}$ & & & $\begin{array}{l}-0.0970^{* * *} \\
(0.0372)\end{array}$ & $\begin{array}{l}-0.0770^{*} \\
(0.0402)\end{array}$ & $\begin{array}{l}-0.1546^{* * * *} \\
(0.0515)\end{array}$ & $\begin{array}{l}-0.1218^{* * *} \\
(0.0419)\end{array}$ & $\begin{array}{l}-0.0881 \\
(0.0689)\end{array}$ & $\begin{array}{l}-0.0407 \\
(0.0723)\end{array}$ & $\begin{array}{l}-0.0442 \\
(0.0857)\end{array}$ \\
\hline$q$ & & & & $\begin{array}{l}0.0056 \\
(0.0035)\end{array}$ & & $\begin{array}{l}0.0104^{* * *} \\
(0.0037)\end{array}$ & $\begin{array}{l}0.0102^{* * *} \\
(0.0037)\end{array}$ & $\begin{array}{l}0.0127^{* * *} \\
(0.0045)\end{array}$ & $\begin{array}{l}0.0130^{* * *} \\
(0.0040)\end{array}$ & $\begin{array}{l}-0.0024 \\
(0.0050)\end{array}$ & $\begin{array}{l}0.0004 \\
(0.0049)\end{array}$ & $\begin{array}{l}0.0001 \\
(0.0053)\end{array}$ \\
\hline$\frac{\text { cash }}{\text { assets }}$ & & & & & $\begin{array}{l}0.0479 \\
(0.0342)\end{array}$ & $\begin{array}{l}0.0134 \\
(0.0368)\end{array}$ & $\begin{array}{l}0.0139 \\
(0.0368)\end{array}$ & $\begin{array}{l}-0.0132 \\
(0.0418)\end{array}$ & $\begin{array}{l}0.0295 \\
(0.0419)\end{array}$ & $\begin{array}{l}-0.0301 \\
(0.0493)\end{array}$ & $\begin{array}{l}-0.0452 \\
(0.0500)\end{array}$ & $\begin{array}{l}-0.0153 \\
(0.0617)\end{array}$ \\
\hline Avg. tax rate & & & & & & & $\begin{array}{l}0.0123 \\
(0.0155)\end{array}$ & & & & & \\
\hline Mrg. tax rate & & & & & & & & $\begin{array}{l}0.0697 \\
(0.0669)\end{array}$ & & & & $\begin{array}{l}0.1317 \\
(0.0935)\end{array}$ \\
\hline Small tax loss & & & & & & & $\begin{array}{l}-0.0045 \\
(0.0116)\end{array}$ & & & & & \\
\hline Large tax loss & & & & & & & $\begin{array}{l}0.0162 \\
(0.0118)\end{array}$ & & & & & \\
\hline$\frac{R \& D}{\text { sales }}$ & & & & & & & & & $\begin{array}{l}-0.0970^{*} \\
(0.0542)\end{array}$ & & & $\begin{array}{l}0.0349 \\
(0.0975)\end{array}$ \\
\hline Firm age & & & & & & & & & & $\begin{array}{l}-0.0026^{*} \\
(0.0015)\end{array}$ & $\begin{array}{l}-0.0020 \\
(0.0015)\end{array}$ & $\begin{array}{l}-0.0010 \\
(0.0015)\end{array}$ \\
\hline$\%$ negative sales growth & & & & & & & & & & $\begin{array}{l}-0.1270^{* * *} \\
(0.0358)\end{array}$ & & \\
\hline$\%$ negative cash flow & & & & & & & & & & $\begin{array}{l}0.0834^{* *} \\
(0.0410)\end{array}$ & & \\
\hline$\%$ sales growth $<\mu_{i n d}-\sigma_{\text {ind }}$ & & & & & & & & & & & $\begin{array}{l}-0.0751 \\
(0.0495)\end{array}$ & $\begin{array}{l}-0.0701 \\
(0.0575)\end{array}$ \\
\hline$\%$ cash flow $<\mu_{i n d}-\sigma_{i n d}$ & & & & & & & & & & & $\begin{array}{l}0.1312^{* *} \\
(0.0515)\end{array}$ & $\begin{array}{l}0.1336^{* *} \\
(0.0627)\end{array}$ \\
\hline $\operatorname{adj} . R^{2}$ & $13.78 \%$ & $12.76 \%$ & $13.41 \%$ & $12.61 \%$ & $12.90 \%$ & $14.40 \%$ & $14.40 \%$ & $13.66 \%$ & $14.67 \%$ & $14.49 \%$ & $13.99 \%$ & $12.55 \%$ \\
\hline F-Statistic & 35.96 & 25.26 & 32.82 & 25.78 & 28.21 & 15.57 & 10.93 & 12.17 & 12.31 & 7.62 & 6.52 & 4.40 \\
\hline p-value & 0.000 & 0.000 & 0.000 & 0.000 & 0.000 & 0.000 & 0.000 & 0.000 & 0.000 & 0.000 & 0.000 & 0.000 \\
\hline Observations & 1649 & 1649 & 1637 & 1507 & 1649 & 1498 & 1498 & 1245 & 1390 & 888 & 888 & 715 \\
\hline
\end{tabular}


Panel B: Dependent Variable: Rental Payments / (Rental Payments + Capital Expenditures)

\begin{tabular}{|c|c|c|c|c|c|c|c|c|c|c|c|c|}
\hline Regression & 1 & 2 & 3 & 4 & 5 & 6 & 7 & 8 & 9 & 10 & 11 & 12 \\
\hline $\log ($ assets $)$ & $\begin{array}{l}-0.0241^{* * *} \\
(0.0029)\end{array}$ & $\begin{array}{l}-0.02761^{* * *} \\
(0.0029)\end{array}$ & $\begin{array}{l}-0.0241^{* * *} \\
(0.0029)\end{array}$ & $\begin{array}{l}-0.0274^{* * *} \\
(0.0030)\end{array}$ & $\begin{array}{l}-0.0271^{* * *} \\
(0.0029)\end{array}$ & $\begin{array}{l}-0.0250^{* * *} \\
(0.0033)\end{array}$ & $\begin{array}{l}-0.0244^{* * *} \\
(0.0033)\end{array}$ & $\begin{array}{l}-0.0225^{* * *} \\
(0.0036)\end{array}$ & $\begin{array}{l}-0.0250^{* * *} \\
(0.0034)\end{array}$ & $\begin{array}{l}-0.0175^{* * *} \\
(0.0044)\end{array}$ & $\begin{array}{l}-0.0149^{* * *} \\
(0.0043)\end{array}$ & $\begin{array}{l}-0.0142^{* * *} \\
(0.0049)\end{array}$ \\
\hline$\frac{\text { dividends }}{\text { assets }}$ & $\begin{array}{l}-1.1067^{* * *} \\
(0.2736)\end{array}$ & & & & & $\begin{array}{l}-0.7411^{* *} \\
(0.3044)\end{array}$ & $\begin{array}{l}-0.7030^{* *} \\
(0.3032)\end{array}$ & $\begin{array}{l}-0.9826^{* * *} \\
(0.3017)\end{array}$ & $\begin{array}{l}-0.7271^{* *} \\
(0.3260)\end{array}$ & $\begin{array}{l}-0.7039^{*} \\
(0.3802)\end{array}$ & $\begin{array}{l}-0.6597^{*} \\
(0.3874)\end{array}$ & $\begin{array}{l}-1.0112^{* *} \\
(0.4201)\end{array}$ \\
\hline$\frac{\text { long-term debt }}{\text { assets }}$ & (0.2100) & $\begin{array}{l}0.1023^{* * *} \\
(0.0300)\end{array}$ & & & & $\begin{array}{l}0.0624^{*} \\
(0.0374)\end{array}$ & $\begin{array}{l}0.0625^{*} \\
(0.0374)\end{array}$ & $\begin{array}{l}0.0299 \\
(0.0430)\end{array}$ & $\begin{array}{l}0.0517 \\
(0.0385)\end{array}$ & $\begin{array}{l}0.0427 \\
(0.0447)\end{array}$ & $\begin{array}{l}0.0305 \\
(0.0442)\end{array}$ & $\begin{array}{l}0.0216 \\
(0.0505)\end{array}$ \\
\hline$\frac{\text { cash flow }}{\text { assets }}$ & & & $\begin{array}{l}-0.2428^{* * *} \\
(0.0553)\end{array}$ & & & $\begin{array}{l}-0.2177^{* * *} \\
(0.0570)\end{array}$ & $\begin{array}{l}-0.1788^{* * *} \\
(0.0605)\end{array}$ & $\begin{array}{l}-0.2807^{* * *} \\
(0.0789)\end{array}$ & $\begin{array}{l}-0.2515^{* * *} \\
(0.0658)\end{array}$ & $\begin{array}{l}-0.2888^{* *} \\
(0.1315)\end{array}$ & $\begin{array}{l}-0.2730^{* *} \\
(0.1280)\end{array}$ & $\begin{array}{l}-0.1586 \\
(0.1361)\end{array}$ \\
\hline$q$ & & & & $\begin{array}{l}-0.0146^{* * *} \\
(0.0052)\end{array}$ & & $\begin{array}{l}-0.0051 \\
(0.0055)\end{array}$ & $\begin{array}{l}-0.0054 \\
(0.0055)\end{array}$ & $\begin{array}{l}-0.0019 \\
(0.0060)\end{array}$ & $\begin{array}{l}-0.0023 \\
(0.0058)\end{array}$ & $\begin{array}{l}-0.0114 \\
(0.0083)\end{array}$ & $\begin{array}{l}-0.0077 \\
(0.0079)\end{array}$ & $\begin{array}{l}-0.0118 \\
(0.0088)\end{array}$ \\
\hline$\frac{\text { cash }}{\text { assets }}$ & & & & & $\begin{array}{l}-0.0989^{* *} \\
(0.0423)\end{array}$ & $\begin{array}{l}-0.0640 \\
(0.0451)\end{array}$ & $\begin{array}{l}-0.0616 \\
(0.0449)\end{array}$ & $\begin{array}{c}-0.0941^{*} \\
(0.0529)\end{array}$ & $\begin{array}{l}-0.0308 \\
(0.0479)\end{array}$ & $\begin{array}{l}-0.0687 \\
(0.0622)\end{array}$ & $\begin{array}{l}-0.0811 \\
(0.0620)\end{array}$ & $\begin{array}{l}-0.0431 \\
(0.0743)\end{array}$ \\
\hline Avg. tax rate & & & & & & & $\begin{array}{l}0.0280 \\
(0.0220)\end{array}$ & & & & & \\
\hline Mrg. tax rate & & & & & & & & $\begin{array}{l}-0.0290 \\
(0.1063)\end{array}$ & & & & $\begin{array}{l}-0.0776 \\
(0.1551)\end{array}$ \\
\hline Small tax loss & & & & & & & $\begin{array}{l}-0.0032 \\
(0.0161)\end{array}$ & & & & & \\
\hline Large tax loss & & & & & & & $\begin{array}{l}0.0328^{* *} \\
(0.0168)\end{array}$ & & & & & \\
\hline$\frac{\mathrm{R} \& \mathrm{D}}{\text { sales }}$ & & & & & & & & & $\begin{array}{l}-0.1902^{* *} \\
(0.0906)\end{array}$ & & & $\begin{array}{l}-0.0812 \\
(0.1587)\end{array}$ \\
\hline Firm age & & & & & & & & & & $\begin{array}{l}-0.0024 \\
(0.0019)\end{array}$ & $\begin{array}{l}-0.0022 \\
(0.0019)\end{array}$ & $\begin{array}{l}-0.0014 \\
(0.0020)\end{array}$ \\
\hline$\%$ negative sales growth & & & & & & & & & & $\begin{array}{l}-0.0736 \\
(0.0534)\end{array}$ & & \\
\hline \% negative cash flow & & & & & & & & & & $\begin{array}{l}0.0937 \\
(0.0668)\end{array}$ & & \\
\hline$\%$ sales growth $<\mu_{i n d}-\sigma_{i n d}$ & & & & & & & & & & & $\begin{array}{l}0.0664 \\
(0.0783)\end{array}$ & $\begin{array}{l}0.0216 \\
(0.0891)\end{array}$ \\
\hline$\%$ cash flow $<\mu_{i n d}-\sigma_{\text {ind }}$ & & & & & & & & & & & $\begin{array}{l}0.0863 \\
(0.0627)\end{array}$ & $\begin{array}{l}0.1030 \\
(0.0708)\end{array}$ \\
\hline $\operatorname{adj} . R^{2}$ & $11.85 \%$ & $11.57 \%$ & $13.13 \%$ & $11.04 \%$ & $11.20 \%$ & $14.09 \%$ & $14.29 \%$ & $14.22 \%$ & $14.17 \%$ & $13.14 \%$ & $13.24 \%$ & $12.23 \%$ \\
\hline F-Statistic & 53.58 & 49.01 & 56.34 & 44.19 & 43.54 & 24.08 & 17.38 & 18.92 & 18.64 & 9.27 & 9.62 & 6.04 \\
\hline p-value & 0.000 & 0.000 & 0.000 & 0.000 & 0.000 & 0.000 & 0.000 & 0.000 & 0.000 & 0.000 & 0.000 & 0.000 \\
\hline Observations & 1625 & 1625 & 1614 & 1486 & 1625 & 1478 & 1478 & 1229 & 1373 & 885 & 885 & 713 \\
\hline
\end{tabular}


Table 5: Regression Results: Fraction of Capital Services Rented for Structures and Equipment

The table shows the coefficients of regressions of the fraction of capital services rented for structures and equipment on various financial and control variables (controlling for industry dummies at the two digit SIC code level). Heteroscedasticity corrected standard errors are in parenthesis. Data is micro data from a cross section of firms from the 1992 Census of Manufactures for the dependent variables, firm age, and the industry dummies, and from Compustat for financial variables, tax variables, and the standard deviation of sales growth. For a detailed definition of the variables see the description in Table 3. Statistical significance at the $1 \%, 5 \%$, and $10 \%$ level is indicated by ${ }^{* * *},{ }^{* *}$, and ${ }^{*}$, respectively.

Panel A: Structures (Dependent Variable: Rental Payments / (Rental Payments $+r \% \times$ Assets + Depreciation))

\begin{tabular}{|c|c|c|c|c|c|c|c|c|c|c|c|c|}
\hline Regression & 1 & 2 & 3 & 4 & 5 & 6 & 7 & 8 & 9 & 10 & 11 & 12 \\
\hline $\log ($ assets $)$ & $\begin{array}{l}-0.0267^{* * *} \\
(0.0039)\end{array}$ & $\begin{array}{l}-0.0297^{* * *} \\
(0.0038)\end{array}$ & $\begin{array}{l}-0.0298^{* * *} \\
(0.0037)\end{array}$ & $\begin{array}{l}-0.0306^{* * *} \\
(0.0040)\end{array}$ & $\begin{array}{l}-0.0286^{* * *} \\
(0.0038)\end{array}$ & $\begin{array}{l}-0.0253^{* * *} \\
(0.0041)\end{array}$ & $\begin{array}{l}-0.0222^{* * *} \\
(0.0042)\end{array}$ & $\begin{array}{l}-0.0203^{* * *} \\
(0.0044)\end{array}$ & $\begin{array}{l}-0.0265^{* * *} \\
(0.0043)\end{array}$ & $\begin{array}{l}-0.0145^{* * *} \\
(0.0055)\end{array}$ & $\begin{array}{l}-0.0091^{*} \\
(0.0055)\end{array}$ & $\begin{array}{l}-0.0078 \\
(0.0061)\end{array}$ \\
\hline$\frac{\text { dividends }}{\text { assets }}$ & $\begin{array}{l}-1.5478^{* * *} \\
(0.3730)\end{array}$ & & & & & $\begin{array}{l}-1.6945^{* * *} \\
(0.4234)\end{array}$ & $\begin{array}{l}-1.7020^{* * *} \\
(0.4219)\end{array}$ & $\begin{array}{l}-2.0629^{* * *} \\
(0.4307)\end{array}$ & $\begin{array}{l}-1.5139^{* * *} \\
(0.4549)\end{array}$ & $\begin{array}{l}-2.0305^{* * *} \\
(0.4593)\end{array}$ & $\begin{array}{l}-1.9860^{* * *} \\
(0.4773)\end{array}$ & $\begin{array}{l}-1.8993^{* * *} \\
(0.5370)\end{array}$ \\
\hline$\frac{\text { long-term debt }}{\text { assets }}$ & & $\begin{array}{l}-0.0137 \\
(0.0384)\end{array}$ & & & & $\begin{array}{l}-0.0219 \\
(0.0461)\end{array}$ & $\begin{array}{l}-0.0213 \\
(0.0458)\end{array}$ & $\begin{array}{l}-0.0499 \\
(0.0536)\end{array}$ & $\begin{array}{l}-0.0283 \\
(0.0481)\end{array}$ & $\begin{array}{l}-0.0011 \\
(0.0576)\end{array}$ & $\begin{array}{l}-0.0239 \\
(0.0584)\end{array}$ & $\begin{array}{l}-0.0224 \\
(0.0684)\end{array}$ \\
\hline$\frac{\text { cash flow }}{\text { assets }}$ & & & $\begin{array}{l}-0.1617^{* *} \\
(0.0647)\end{array}$ & & & $\begin{array}{l}-0.1807^{* * *} \\
(0.0674)\end{array}$ & $\begin{array}{l}-0.1010 \\
(0.0729)\end{array}$ & $\begin{array}{l}-0.2711^{* * *} \\
(0.0985)\end{array}$ & $\begin{array}{l}-0.1638^{* *} \\
(0.0764)\end{array}$ & $\begin{array}{l}-0.1195 \\
(0.1251)\end{array}$ & $\begin{array}{l}-0.0758 \\
(0.1257)\end{array}$ & $\begin{array}{l}0.0127 \\
(0.1622)\end{array}$ \\
\hline$q$ & & & & $\begin{array}{l}0.0077 \\
(0.0062)\end{array}$ & & $\begin{array}{l}0.0145^{* *} \\
(0.0066)\end{array}$ & $\begin{array}{l}0.0145^{* *} \\
(0.0066)\end{array}$ & $\begin{array}{l}0.0217^{* * *} \\
(0.0077)\end{array}$ & $\begin{array}{l}0.0139^{*} \\
(0.0073)\end{array}$ & $\begin{array}{l}-0.0005 \\
(0.0099)\end{array}$ & $\begin{array}{l}0.0095 \\
(0.0095)\end{array}$ & $\begin{array}{l}-0.0005 \\
(0.0109)\end{array}$ \\
\hline$\frac{\text { cash }}{\text { assets }}$ & & & & & $\begin{array}{l}0.1635^{* * *} \\
(0.0615)\end{array}$ & $\begin{array}{l}0.1084 \\
(0.0667)\end{array}$ & $\begin{array}{l}0.1047 \\
(0.0663)\end{array}$ & $\begin{array}{l}0.0551 \\
(0.0778)\end{array}$ & $\begin{array}{l}0.0950 \\
(0.0758)\end{array}$ & $\begin{array}{l}0.0466 \\
(0.0953)\end{array}$ & $\begin{array}{l}0.0285 \\
(0.0958)\end{array}$ & $\begin{array}{l}0.0403 \\
(0.1137)\end{array}$ \\
\hline Avg. tax rate & & & & & & & $\begin{array}{l}-0.0330 \\
(0.0283)\end{array}$ & & & & & \\
\hline Mrg. tax rate & & & & & & & & $\begin{array}{l}0.0048 \\
(0.1350)\end{array}$ & & & & $\begin{array}{l}0.0614 \\
(0.1997)\end{array}$ \\
\hline Small tax loss & & & & & & & $\begin{array}{l}-0.0173 \\
(0.0220)\end{array}$ & & & & & \\
\hline Large tax loss & & & & & & & $\begin{array}{l}0.0565^{* * *} \\
(0.0217)\end{array}$ & & & & & \\
\hline$\frac{\mathrm{R} \& \mathrm{D}}{\text { sales }}$ & & & & & & & & & $\begin{array}{l}0.0229 \\
(0.1073)\end{array}$ & & & $\begin{array}{l}0.4024^{*} \\
(0.2071)\end{array}$ \\
\hline Firm age & & & & & & & & & & $\begin{array}{l}-0.0054^{* *} \\
(0.0025)\end{array}$ & $\begin{array}{l}-0.0045^{*} \\
(0.0025)\end{array}$ & $\begin{array}{l}-0.0031 \\
(0.0027)\end{array}$ \\
\hline$\%$ negative sales growth & & & & & & & & & & $\begin{array}{l}-0.3216^{* * *} \\
(0.0685)\end{array}$ & & \\
\hline$\%$ negative cash flow & & & & & & & & & & $\begin{array}{l}0.1529^{*} \\
(0.0787)\end{array}$ & & \\
\hline$\%$ sales growth $<\mu_{i n d}-\sigma_{i n d}$ & & & & & & & & & & & $\begin{array}{l}-0.1560 \\
(0.0953)\end{array}$ & $\begin{array}{l}-0.1582 \\
(0.1095)\end{array}$ \\
\hline$\%$ cash flow $<\mu_{\text {ind }}-\sigma_{\text {ind }}$ & & & & & & & & & & & $\begin{array}{l}0.1617^{* *} \\
(0.0825)\end{array}$ & $\begin{array}{l}0.1220 \\
(0.0963)\end{array}$ \\
\hline $\operatorname{adj} . R^{2}$ & $14.39 \%$ & $13.36 \%$ & $14.37 \%$ & $13.19 \%$ & $13.84 \%$ & $15.59 \%$ & $16.02 \%$ & $14.19 \%$ & $15.50 \%$ & $13.92 \%$ & $11.90 \%$ & $10.88 \%$ \\
\hline F-Statistic & 44.67 & 32.42 & 44.11 & 32.90 & 40.08 & 21.08 & 15.58 & 14.83 & 16.16 & 9.15 & 6.39 & 5.52 \\
\hline p-value & 0.000 & 0.000 & 0.000 & 0.000 & 0.000 & 0.000 & 0.000 & 0.000 & 0.000 & 0.000 & 0.000 & 0.000 \\
\hline Observations & 1637 & 1637 & 1625 & 1496 & 1637 & 1487 & 1487 & 1235 & 1379 & 883 & 883 & 710 \\
\hline
\end{tabular}


Panel B: Equipment (Dependent Variable: Rental Payments / (Rental Payments $+r \% \times$ Assets + Depreciation))

\begin{tabular}{|c|c|c|c|c|c|c|c|c|c|c|c|c|}
\hline Regression & 1 & 2 & 3 & 4 & 5 & 6 & 7 & 8 & 9 & 10 & 11 & 12 \\
\hline$\overline{\log (\text { assets })}$ & $\begin{array}{l}-0.0050^{* * *} \\
(0.0014)\end{array}$ & $\begin{array}{l}-0.0059^{* *} \\
(0.0014)\end{array}$ & $\begin{array}{l}-0.0059^{* * *} \\
(0.0014)\end{array}$ & $\begin{array}{l}-0.0061^{* *} \\
(0.0015)\end{array}$ & $\begin{array}{l}-0.0058^{* * *} \\
(0.0014)\end{array}$ & $\begin{array}{l}-0.0057^{* *} \\
(0.0017)\end{array}$ & $\begin{array}{l}-0.0061^{* * *} \\
(0.0017)\end{array}$ & $\begin{array}{l}-0.0055^{* * *} \\
(0.0017)\end{array}$ & $\begin{array}{l}-0.0057^{* * *} \\
(0.0017)\end{array}$ & $\begin{array}{l}-0.0065^{* *} \\
(0.0022)\end{array}$ & $\begin{array}{l}-0.0053^{* * *} \\
(0.0021)\end{array}$ & $\begin{array}{l}-0.0060^{* *} \\
(0.0023)\end{array}$ \\
\hline$\frac{\text { dividends }}{\text { assets }}$ & $\begin{array}{l}-0.3546^{* *} \\
(0.1500)\end{array}$ & & & & & $\begin{array}{l}-0.3283^{*} \\
(0.1874)\end{array}$ & $\begin{array}{l}-0.3062 \\
(0.1876)\end{array}$ & $\begin{array}{l}-0.5204^{* * *} \\
(0.1445)\end{array}$ & $\begin{array}{l}-0.3042 \\
(0.2047)\end{array}$ & $\begin{array}{l}-0.0286 \\
(0.1951)\end{array}$ & $\begin{array}{l}0.0262 \\
(0.2006)\end{array}$ & $\begin{array}{l}-0.1109 \\
(0.1883)\end{array}$ \\
\hline$\frac{\text { long-term debt }}{\text { assets }}$ & & $\begin{array}{l}0.0095 \\
(0.0134)\end{array}$ & & & & $\begin{array}{l}0.0154 \\
(0.0175)\end{array}$ & $\begin{array}{l}0.0152 \\
(0.0175)\end{array}$ & $\begin{array}{l}-0.0094 \\
(0.0175)\end{array}$ & $\begin{array}{l}0.0107 \\
(0.0181)\end{array}$ & $\begin{array}{l}0.0339^{*} \\
(0.0197)\end{array}$ & $\begin{array}{l}0.0283 \\
(0.0193)\end{array}$ & $\begin{array}{l}0.0133 \\
(0.0211)\end{array}$ \\
\hline$\frac{\text { cash flow }}{\text { assets }}$ & & & $\begin{array}{l}-0.0315 \\
(0.0263)\end{array}$ & & & $\begin{array}{l}-0.0304 \\
(0.0274)\end{array}$ & $\begin{array}{l}-0.0245 \\
(0.0285)\end{array}$ & $\begin{array}{l}-0.0921^{* *} \\
(0.0381)\end{array}$ & $\begin{array}{l}-0.0455 \\
(0.0313)\end{array}$ & $\begin{array}{l}-0.0653 \\
(0.0563)\end{array}$ & $\begin{array}{l}-0.0321 \\
(0.0567)\end{array}$ & $\begin{array}{l}-0.0559 \\
(0.0666)\end{array}$ \\
\hline$q$ & & & & $\begin{array}{l}0.0012 \\
(0.0024)\end{array}$ & & $\begin{array}{l}0.0038 \\
(0.0026)\end{array}$ & $\begin{array}{l}0.0037 \\
(0.0026)\end{array}$ & $\begin{array}{l}0.0048 \\
(0.0032)\end{array}$ & $\begin{array}{l}0.0049^{*} \\
(0.0028)\end{array}$ & $\begin{array}{l}-0.0052 \\
(0.0035)\end{array}$ & $\begin{array}{l}-0.0047 \\
(0.0035)\end{array}$ & $\begin{array}{l}-0.0034 \\
(0.0038)\end{array}$ \\
\hline$\frac{\mathrm{cash}}{\operatorname{assets}}$ & & & & & $\begin{array}{l}-0.0017 \\
(0.0218)\end{array}$ & $\begin{array}{l}-0.0049 \\
(0.0229)\end{array}$ & $\begin{array}{l}-0.0034 \\
(0.0229)\end{array}$ & $\begin{array}{l}-0.0275 \\
(0.0244)\end{array}$ & $\begin{array}{l}0.0042 \\
(0.0266)\end{array}$ & $\begin{array}{l}-0.0448 \\
(0.0296)\end{array}$ & $\begin{array}{c}-0.0544^{*} \\
(0.0295)\end{array}$ & $\begin{array}{l}-0.0370 \\
(0.0376)\end{array}$ \\
\hline Avg. tax rate & & & & & & & $\begin{array}{l}0.0199^{*} \\
(0.0118)\end{array}$ & & & & & \\
\hline Mrg. tax rate & & & & & & & & $\begin{array}{l}0.1058^{* *} \\
(0.0511)\end{array}$ & & & & $\begin{array}{l}0.1129^{*} \\
(0.0702)\end{array}$ \\
\hline Small tax loss & & & & & & & $\begin{array}{l}0.0023 \\
(0.0076)\end{array}$ & & & & & \\
\hline Large tax loss & & & & & & & $\begin{array}{l}0.0070 \\
(0.0082)\end{array}$ & & & & & \\
\hline$\frac{\mathrm{R} \& \mathrm{D}}{\text { sales }}$ & & & & & & & & & $\begin{array}{l}-0.0358 \\
(0.0424)\end{array}$ & & & $\begin{array}{l}-0.0045 \\
(0.0989)\end{array}$ \\
\hline Firm age & & & & & & & & & & $\begin{array}{l}-0.0007 \\
(0.0010)\end{array}$ & $\begin{array}{l}-0.0004 \\
(0.0009)\end{array}$ & $\begin{array}{l}-0.0002 \\
(0.0009)\end{array}$ \\
\hline$\%$ negative sales growth & & & & & & & & & & $\begin{array}{l}-0.0422^{*} \\
(0.0250)\end{array}$ & & \\
\hline$\%$ negative cash flow & & & & & & & & & & $\begin{array}{l}0.0398 \\
(0.0308)\end{array}$ & & \\
\hline$\%$ sales growth $<\mu_{i n d}-\sigma_{\text {ind }}$ & & & & & & & & & & & $\begin{array}{l}-0.0188 \\
(0.0370)\end{array}$ & $\begin{array}{l}-0.0034 \\
(0.0417)\end{array}$ \\
\hline$\%$ cash flow $<\mu_{i n d}-\sigma_{i n d}$ & & & & & & & & & & & $\begin{array}{l}0.0783^{* *} \\
(0.0358)\end{array}$ & $\begin{array}{l}0.0755^{*} \\
(0.0409)\end{array}$ \\
\hline $\operatorname{adj} . R^{2}$ & $5.62 \%$ & $5.20 \%$ & $5.33 \%$ & $4.78 \%$ & $5.18 \%$ & $5.26 \%$ & $5.36 \%$ & $6.17 \%$ & $4.94 \%$ & $8.87 \%$ & $9.25 \%$ & $7.79 \%$ \\
\hline F-Statistic & 11.89 & 8.77 & 10.91 & 8.72 & 8.45 & 5.17 & 3.73 & 5.58 & 3.97 & 4.71 & 4.77 & 2.86 \\
\hline $\mathrm{p}$-value & 0.000 & 0.000 & 0.000 & 0.000 & 0.000 & 0.000 & 0.000 & 0.000 & 0.000 & 0.000 & 0.000 & 0.001 \\
\hline Observations & 1649 & 1649 & 1637 & 1507 & 1649 & 1498 & 1498 & 1245 & 1390 & 888 & 888 & 715 \\
\hline
\end{tabular}




\section{Figure 1: Investment in Owned Capital and Leased Capital}

Top Left Panel: Investment in owned capital (dash dotted), leased capital (solid), and total investment (dotted) as a function of the amount of internal funds. Middle Left Panel: Leased capital as percentage of total capital. Bottom Left Panel: Return on internal funds $\mu_{0}$ (solid) as a function of the amount of internal funds. The downward sloping lines (dashed) are the marginal product of capital in appropriate in the various ranges and the horizontal lines (dashed) are the values of $\mu_{0}^{1}, \mu_{0}^{2}, \mu_{0}^{3}$, and $R$, respectively. See the appendix for details. Top Right Panel: Explicit debt (dash dotted) and implicit (leasing) debt (solid). Bottom Right Panel: Fraction of leased capital repossessed (solid) and fraction of owned capital repossessed in state $L$ (dash dotted) as a function of the amount of internal funds. Parameter Values: Technology: $\alpha=0.33, \delta=0.1, \delta_{l}=0.15, \pi(H)=\pi(L)=0.5$; Collateralization Rate: $\theta=0.90$; Distribution of Internal Funds: $\mathcal{E}=[0.001: 0.001: 0.8], \pi(e)=[1 / 800, \ldots, 1 / 800]$; Equilibrium Gross Interest Rate: $R=1.165$.
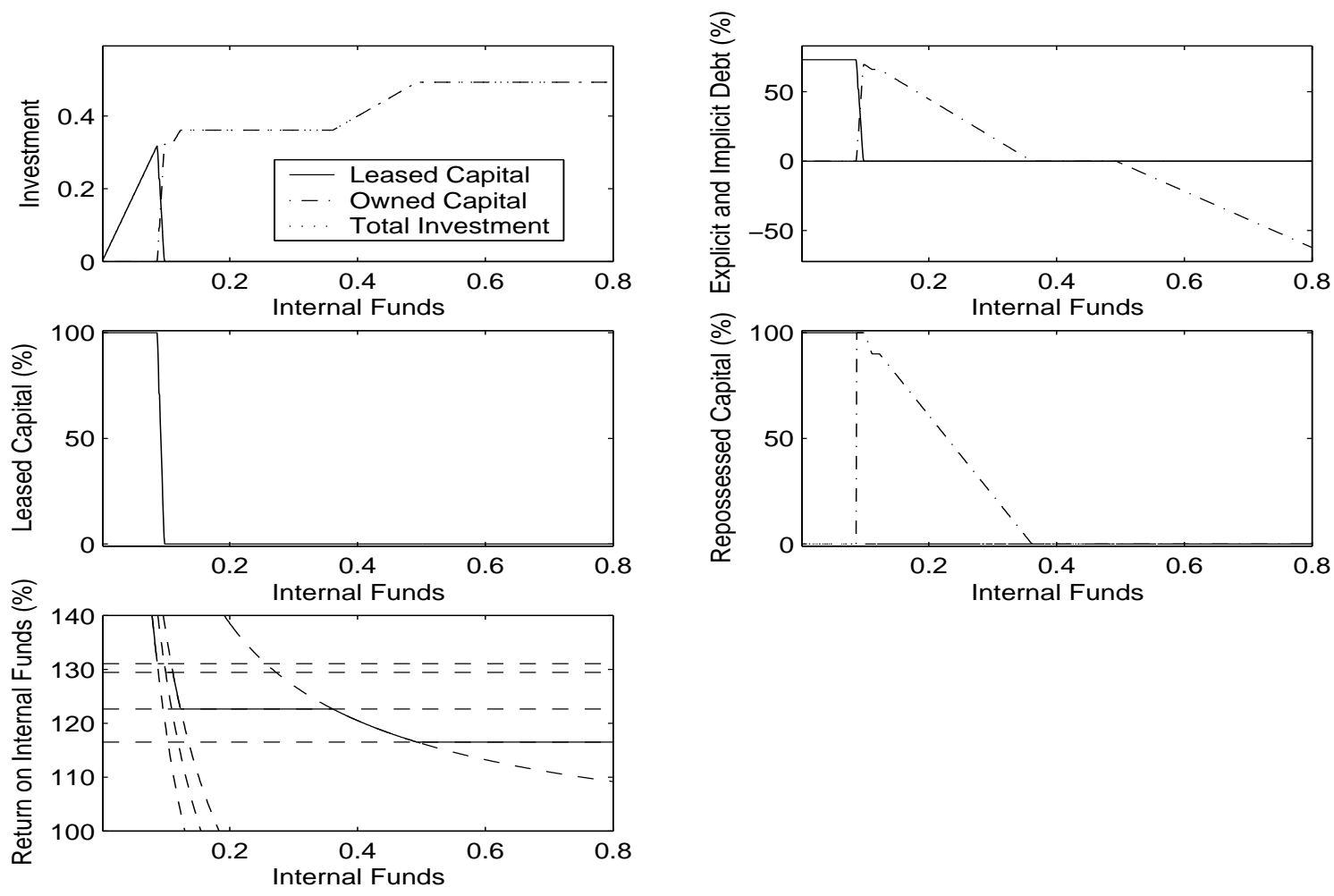


\section{Figure 2: Ratio of Rental Payments to Total Payments for Capital Services Across Asset Deciles}

Fraction of rental payments (including payments on operating leases) relative to total payments for capital services (sum of rental payments, interest rate times total assets, and depreciation) across asset deciles for total capital (solid), buildings and other structures (dashed), and machinery and equipment (dotted). We use the 1992 Census of Manufactures micro data. See Table 2 for a detailed description of the data construction.

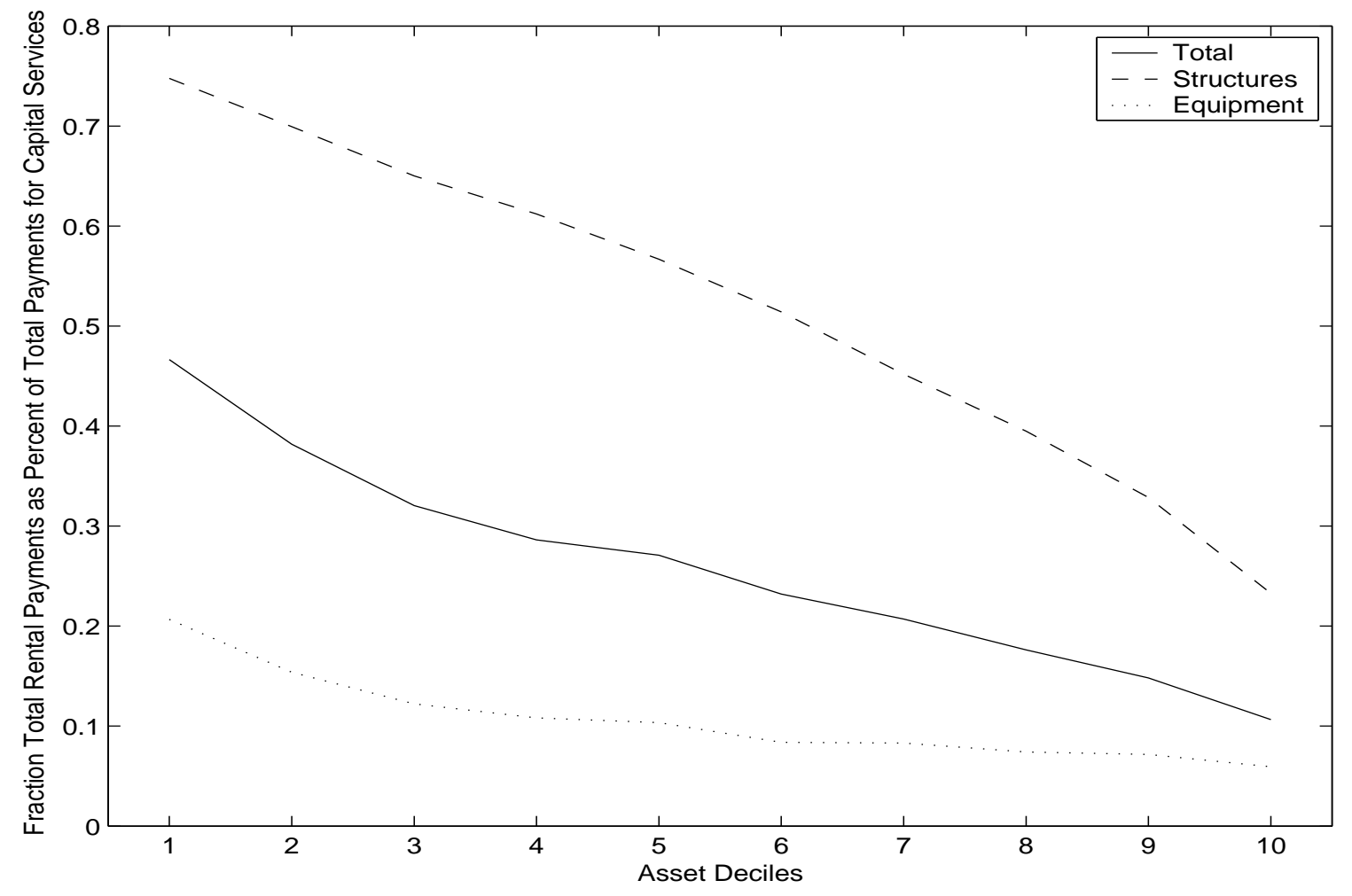

